\title{
The Impact of Customer Experience in Online Brand Communities on Customer Engagement and Purchase Intentions Among Arab Internet Users: Theoretical Analysis, Conceptual Framework and Research Agenda
}

\author{
Sherif Akram ${ }^{1} \&$ Wael Kortam ${ }^{2}$ \\ ${ }^{1}$ DBA Candidate, Major: Marketing, Business Administration Department Faculty of Commerce, Cairo University, Egypt \\ ${ }^{2}$ Professor of Marketing, Head of Business Administration Department, Faculty of Commerce, Cairo University, Egypt \\ Correspondence: Sherif Akram, DBA Candidate, Major: Marketing, Business Administration Department Faculty of \\ Commerce, Cairo University, Egypt. E-mail: Sherifakram298@gmail.com; Sakram@arado.org
}

Received: August 21, 2020

doi:10.11114/bms.v6i3.5021
Accepted: September 14, 2020

Online Published: September 17, 2020

\begin{abstract}
Drawing on the service ecosystem theory and customer experience and engagement theory, this study examines the relationship between customer experience, customer engagement, and purchase intentions in online settings. Customer experience is operationalized into pragmatic, hedonic, sociability, and usability, whereas customer engagement is operationalized into the attitudinal and behavioral engagement. This study was undertaken among members of online communities from The Arab Administrative Development Organization (ARADO); a specialized organization affiliated with the League of Arab States. The study delves identifying into which customer experience may elevate customer engagement, how the specific customer experience elevates customer engagement to potentially lead to a purchasing intention in online brand communities.
\end{abstract}

Keywords: service ecosystem, online community, customer experience, customer engagement, purchase intention, value co-creation, community engagement

\section{Introduction}

Over the last 15 years, a large and growing body of literature has explored the growth internet marketing. Marketing research and practice, which are needed for strategic and international marketing activities, proposed a conceptual framework for the diffusion of the internet marketing. This would be done through the values created by the interaction of internet technologies, strategic modern marketing thinking and the agenda of practice. Moreover, studies have illustrated the impact of those interactions in building and sustaining an organization's global competitive advantage (Kortam, W. 2006).

Several attempts have been made by organizations to penetrate in the growing online brand community (OBC). These organizations invest their resources to their increase brand equity (Chow and Shi, 2015; Royo-Vela and Casamassima, 2011; Zhang and Luo, 2016). OBC is a virtual connection between brand and individuals through social media/networks platforms, which allows individuals expressing similar interests in the business to share a system of values (Rheingold, 1993). Social media such as Facebook, LinkedIn, and Twitter, as a form of OBC, enable individual profiles to create interpersonal relationships that psychologically represented through intimate and continuous communications (Xu et al., 2012). There are distinct characteristics that differentiate online from offline brand communities. Through the online brand community, individuals can access products faster and more comprehensively and therefore save effort, time, and money (Wirtz et al., 2013).

According to Muniz and O'Guinn (2001), OBC consists of the brand/organization, customers, and stakeholders The community allows participants or members to share their experiences by expressing their feelings, posting comments, sending advice or obtaining feedback. Although the organization or brand manages the online community as well as participant's activities, participants themselves seek to interact with other participants. Because the organization/brand aims to increase its market share, the community participants therefore become a virtual friend of the organization through their online interactions (Ridings et al., 2002).

From a different practical and academic perspective, the enhancement of customer experiences leads to realized 
purchase intentions through customer engagement. Firstly, from a practical standpoint, digital marketing strategies changed to focus on attracting proactively engaged followers by presenting distinctive customer experiences in dynamically interactive media platforms as opposed to increasing the numbers of their followers (Park and Kim, 2014; Simon et al., 2016). Many online organization platforms, for example, Dell, have positively increased customers' internal motivation to involve, participate, and recommend (Baldus et al., 2015). Secondly, from an academic perspective, a plethora of controversies has emerged about customer engagement (CE) in online organizational platforms (Baldus et al., 2015; Brodie et al., 2013).

Customer engagement, which dependent on a satisfying customer experience, refers to a customer's rational state, which in turn is demonstrated through positive behaviors and attitudes towards a brand and community advertising. Thus, this research questions whether the relationship between customer experience and purchase intention is impacted by the intermediate effect of customer engagement in online brand communities (Chang et al., 2013; Schamari and Schaefers, 2015).

Based on both theories (customer experience and service ecosystem) and a review of current, this research study has developed a conceptual framework of the customer experience (pragmatic, hedonic, Sociability and Usability), customer engagement (attitudinal, behavioral), and purchase intention to enhance the understanding of relationships between these variables. It is anticipated that this research will illustrate how customer engagement depends modifies customer experience in enhancing purchase intention in OBC settings. In addition to improving those theories, customer engagement and service ecosystem could potentially be applied to the online brand community in the Arab internet user's context.

This research study question shall take into consideration in the final conclusion: firstly, Developing social networks, a lot of customer's access to brand communities on their platforms. Therefore, the user-behavior patterns across communication channels may vary (Okazaki et al., 2014). Secondly, this study will be conducted on the Arab internet user; because the perception of communication platforms and characteristics, and customer experiences may also differ, the results of this study may not be generalizable.

\section{Theoretical Background}

The critical and analytical literature review covered ten research streams and venues; mainly: Service Ecosystem, Online community, Evaluation of customer experience and customer engagement, Evaluation of customer engagement and purchase intention, Continuing value co-creation, Deductive service ecosystem theory on online brand communities, Online customer experience (OCX), online customer engagement (OCE), Value co-creation and finally Community engagement.

\subsection{Service Ecosystem}

Many contemporary researchers, e.g. Vargo and Lusch (2011) paid particular attention to the logic of service-dominant (SD). SD expand the co-creation framework to a systematic view of the service ecosystem. In the literature, this is referred to as "relatively self-contained, self-adjusting systems of resource-integrating actors connected by shared institutional logics and mutual value creation through service exchange." (Vargo and Akaka, 2012). Value co-creation is achieved through a shared continuous interlinked organized logic between all social and economic actors, which exceed the firm customer relations (Vargo and Lusch, 2011).

\subsection{Online Community}

Recently, literature has been increasingly focused on online communities that allow members to connect, interact, quit or switch their communities. The degree of user engagement with the brand or the business depends on the duration of participants' interaction with other members. This duration in turn is an indicator of the members' commitment.

Surveys such as those conducted by Wang and Fesenmaier (2004), revealed that in the online travel community, user involvement status had an impact on the level of user contribution. Numerous researchers have argued that participants that differ demographically also differ in the degree of identification with the organization and perform in a deferent way through the community (Dutton et al., 1994; Wang and Fesenmaier, 2004). Recent evidence suggests that newer participants might identify less with the brand, but they attempt to familiarize with the community that which shares their values and interests (Prentice et al., 2018).

Previous studies have reported that interactions between newer and older members may expedite the process of identification with other members and the community. Additionally, a former member who is deeply involved in the community, may act as a leader who influences the community, attracts more members, and draws other members to join the community (Thompson and Sinha, 2008).

Furthermore, the different durations of membership has a positive impact on customer engagement and purchasing 
intention (Wang and Fesenmaier, 2004). Researchers usually consider the online community as one of the essential type that impacts on online communications and suggestions (Kusumasondjaja, 2012). Moreover, due to the interactive nature of online communities and low switching costs, members can join or leave such online communities at no cost. Therefore, it is understandable that people would choose to participate in an online community and spend their time and energy in community activities. Although previous Research has addressed various factors affecting the online community engagement among members, limited research has been conducted to comprehensively incorporate different elements and different perspectives that influence online community engagement.

\subsection{Evaluation of Customer Experience and Engagement}

Recent evidence suggests that customer experience and value co-creation represent a vital component in shifting from a product- and firm-centric view to a personalized consumer experience (Prahalad and Ramaswamy, 2004). Several studies have examined the highly contextual nature of co-created value and found that The customer is always a co-creator of value, and The enterprise cannot deliver value, but only offer value propositions (Vargo and Lusch, 2008). Previous research that evaluated customers' experience during service encounters have produced results consistent with the service ecosystem at the micro-level. The service ecosystem posits that customers can share and co-create their experience through a particular service context (Akaka et al., 2015).

In vitro studies have shown that through the service ecosystem, consumers can assess their experiences based on their interaction with other customers, stockholders, and organizations (Vargo and Lusch, 2011). Numerous studies have illustrated that some type of communication and co-created customer experience may be attained to the level of customer engagement performance when the customers exhibit behaviors that are beyond regular transactions (Lusch and Vargo, 2010; Vargo and Lusch, 2014).

Customer engagement (CE) is considered a solid part of this service ecosystem, by referring to "the importance of establishing and maintaining enduring, value-laden interactive customer relationships." (Brodie et al., 2011).

\subsection{Evaluation of $C E$ and Purchase Intention}

Online brand networks are special platforms that are created and published to facilitate and reinforce customer engagement and enhance the relationship between the organization and online members, increase customer involvement and loyalty as well as increasing the organization's market share.

The positive and direct relationship between customer loyalty and customer purchase intentions has been extensively investigated in the literature (Brodie et al., 2011; Gummerus et al., 2012; Hollebeek, 2011; Prentice et al., 2018; Vivek et al., 2012). It has conclusively been shown that when both the percentage of customer engagement and customer loyalty are increased, this can promote the success of a brand (So et al., 2014).

\subsection{Continuing Value Co-creation}

The dynamics of service systems is one of the essential components of the service ecosystem (Akaka and Vargo, 2015). Previous studies have reported that embracing the provisions of the ecosystem as self-adjusting and self-containing enables the co-creation process value to spread outwards to the following round of service encounter along with the actor's co-creation future intention, as opposed to it ending after a service encounters (Akaka and Vargo, 2015; Akaka et al., 2013; Vargo and Lusch, 2011). Surveys such as those conducted by Akaka et al. (2013), have shown that the actively engaged customers who share and recommend the brand to other members improve the customer experience. Word of mouth testimonies, therefore remain as a form of value co-creation.

It has conclusively been shown that word of mouth (WOM) testimonials promote the continuous process of value co-creation by broadening the location and time dimensions of co-creation value and the perceptions of the previous service engagement experience that is shared during referrals (Akaka et al., 2013; Vargo and Lusch, 2008). Recent evidence suggests that continuous value co-creation is defined as interactive engagement by customers that share a positive service engagement experience (Akaka et al., 2013).

\subsection{Deductive Service Ecosystem Theory on OBC Study}

Several studies have noted that OBCs could be regarded as adequate virtual networks that effectively and efficiently reinforce social interaction (Lusch and Nambisan, 2015). On the one hand, brand members act together with others through the communities to co-create exclusive experiences for each member thereby promoting members' interaction. The flexible and open environments of online contexts allow for interactions among different entities beyond the customer-firm dyad. On the other hand, OBCs' customers are transformed from conventional inactive participants into active participants. The shaping of engaged clients is in line with the service ecosystem that reframes the functions of members and resources (Koskela-Huotari et al., 2016).

The active engagement of clients in activities such as assisting others, bonding in relations, and promotion of 
community can steer the cycle of continuing co-creation value through behavioral engagement (Van Doorn et al., 2010).

In summary, the theory of the service ecosystem provides a central paradigm that associates the consumer experience concepts that are co-created through interactions. Furthermore, engagement (as a result of customer experience assessment) and WOM intention (as a display of the behavior of dynamically engaged clients) can lead to continued value co-creation in network/online brand communities (OBCs).

\subsection{Online Customer Experience (OCX)}

Previous studies have reported that customer experience has viewed as a psychological sensation in the form of a subjective reaction or total perception that complements service delivery (Lewis and Chambers, 2000). This proposed research refers to the recent related works of customer experience in an online environment summarized in Table I.

Moreover, psychology and communication research identify two main factors used to assess the cognitive and active components of human experience (Blumler, 1979; Forgas, 2000). The first component is the cognitive dimension, which emphasizes the perspective of information processing. Conversely, the second component is experience, which underlies the acquisition and processing of information. Experience is the affective dimension reflecting the feelings and emotions derived from the external environment and interactions with stimuli. These two elements have also been conceptualized in various ways as "utilitarian" and "hedonic" and as "extrinsic" and "intrinsic" dimensions (Babin et al., 1994; Batra and Ahtola, 1991; Dhar and Wertenbroch, 2000; Hirschman and Holbrook, 1982; Noble et al., 2005; Overby and Lee, 2006; Voss et al., 2003).

Beginning in the mid-1990s, this two-dimensional interface paradigm was used by several researchers to examine customer experiences of online environments. For example, in the context of online shopping experiences, web browsing behavior, and online retail activity (Babin et al., 1994; Bridges and Florsheim, 2008; Hoffman and Novak, 1996; Jones et al., 2006; Mathwick et al., 2001; Noble et al., 2005; Overby and Lee, 2006).

Such experiments usually focus on an interaction that is conceptualized as a monolithic structure (e.g., Web experience for consumers) or a two-dimensional structure that focuses exclusively on functional/hedonic aspects. In similar terms, Hoffman and Novak (1996) suggest that the definition of "flow" would classify the two dimensions as "goals-oriented" and "experiential"(Csikszentmihalyi, 1990).

Table 1. Customer experience in the online context

\begin{tabular}{|c|c|c|}
\hline Authors & Measurement & Description \\
\hline \multirow{5}{*}{$\begin{array}{l}\text { "(Schmitt, 1999) } \\
\text { (Chen and Lin, } \\
2015) \\
\text { (Delgado-Ballester } \\
\text { and Fernandez } \\
\text { Sabiote, 2015)" }\end{array}$} & "Sense" & "Experience that derives from the five senses (sight, hearing, smell, taste, and touch)." \\
\hline & "Feel" & "Experience that stimulates the inner feelings and emotions of the customer." \\
\hline & "Think" & "Experience that facilitates user groups to think more creatively using creative methods." \\
\hline & “Act" & $\begin{array}{l}\text { "Experience that integrates numerous behavioral options, such as physical activities, } \\
\text { living patterns, and interaction." }\end{array}$ \\
\hline & "Relate" & $\begin{array}{l}\text { "Experience that transcends individual and personal emotions, associating the ideal self } \\
\text { with other people or cultures." }\end{array}$ \\
\hline \multirow{2}{*}{ 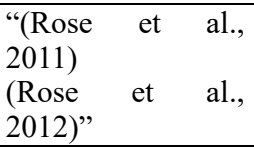 } & $\begin{array}{l}\text { "Cognitive } \\
\text { State" }\end{array}$ & "Experience connected with thinking or conscious mental processes." \\
\hline & $\begin{array}{l}\text { "Affective } \\
\text { State" }\end{array}$ & $\begin{array}{l}\text { "Experience that involves one's affective system through the generation of moods, } \\
\text { feelings, and emotions." }\end{array}$ \\
\hline \multirow{5}{*}{$\begin{array}{l}\text { "(Gentile et al., } \\
\text { 2007) } \\
\text { (Pentina } \\
\text { et al., 2011)" }\end{array}$} & "Sensory" & $\begin{array}{l}\text { "Experiencing aesthetic pleasure and sense of beauty through the organs of sight and } \\
\text { hearing." }\end{array}$ \\
\hline & "Cognitive" & "Engaging in creative problem solving and product/service co-creation." \\
\hline & "Emotional" & "Evoking moods, feelings, and emotions in connection with the shopping process." \\
\hline & "Pragmatic" & "Exhibiting actions of using the interface to accomplish shopping goals." \\
\hline & "Relational" & $\begin{array}{l}\text { "Developing fellowship with other shoppers, sense of belonging to a social group, } \\
\text { affirming particular values and lifestyles." }\end{array}$ \\
\hline \multirow{4}{*}{$\begin{array}{l}\text { "(Nambisan } \\
\text { Watt, 2011) } \\
(\text { Zhang et } \\
2015) "\end{array}$} & $\begin{array}{l}\text { "Pragmatic } \\
\text { Experience" }\end{array}$ & $\begin{array}{l}\text { "Pragmatic or utilitarian value a customer experiences from the interactions in the online } \\
\text { product community." }\end{array}$ \\
\hline & $\begin{array}{l}\text { "Hedonic } \\
\text { Experience" }\end{array}$ & $\begin{array}{l}\text { "Intrinsic value a customer derives from the interactions in the online product } \\
\text { community." }\end{array}$ \\
\hline & $\begin{array}{l}\text { "Sociability } \\
\text { Experience" }\end{array}$ & $\begin{array}{l}\text { "Social experience a customer derives from the interactions in the online product } \\
\text { community." }\end{array}$ \\
\hline & $\begin{array}{l}\text { "Usability } \\
\text { Experience" }\end{array}$ & "A customer's experience in navigating and using the online community environment." \\
\hline \multirow[t]{3}{*}{$\begin{array}{l}\text { "(Zhang et al., } \\
\text { 2014)" }\end{array}$} & $\begin{array}{l}\text { "Social } \\
\text { Support" }\end{array}$ & $\begin{array}{l}\text { "Individual's perception or experience of being cared for, responded to, and helped by } \\
\text { people in one's social group." }\end{array}$ \\
\hline & $\begin{array}{l}\text { "Social } \\
\text { Presence" }\end{array}$ & "A user's sense of psychological connections with other users in a medium." \\
\hline & "Flow" & "Holistic that people feel when they act with total involvement." \\
\hline
\end{tabular}


As mentioned previously, there are two critical issues related to the research in question. Firstly, online product groups are a networking environment for consumers. Secondly, such environments are computer-mediated interactions. Therefore, a broader conceptualization of customer experience that is beyond the pragmatic/hedonic context ought to be looked into. This general conceptualization has dominated current research studies on online customer experiences, including the sociality of customers and usability experience. The results of this research shall enhance the visibility of the online product community, not only as a tool for knowledge discovery and the processing of information, but also as an online social space.

\subsection{Online Customer Engagement (OCE)}

The conceptual origins of customer engagement are explained by the "relationship marketing theory," "value co-creation," and social interaction and interactive experience (Brodie et al., 2011; Harmeling et al., 2017; Jaakkola and Alexander, 2014; Verleye et al., 2014). An actively bound customer that networks with stakeholders and organizations cooperatively and actively can create value co-creation via offering supplies (Vargo and Lusch, 2016; Vargo et al., 2008).

As opposed to the positive parity aspects, Hollebeek and Chen (2014) collect the negative parity terms to supply a complete conceptual framework of customer engagement. Nevetheless, different researchers focus on different definitions of customer engagement (Table 2). CE definitions entail "cognitive, emotional, behavioral and social perspectives" (Brodie et al., 2011; Hollebeek et al., 2014; Hollebeek et al., 2016; Hollebeek, 2011a, 2011b; Verhoef et al., 2010). Moreover, Hollebeek (2011) analysis deems 'immersion, passion, and activation' as key brand engagement themes, which refers to the level at which a customer uses cognitive, emotional, and behavioral resources in specific 'offer' interactions with a pivot brand. Currently, strategies are proposed to fruitfully manage satisfaction in (two by two) customer engagement metrics (Pansari and Kumar., 2017).

Besides this, scholars reiterate that a social aspect of CE imitates the network of actively linked shareholders (Brodie et al., 2013; Groeger et al., 2016; Hollebeek et al., 2016; Vivek et al., 2014).

Recent evidence proposes that when a client seeks information regarding a product and a brand, he/she uses electronic tools to buy services, purchase goods or download apps related to the brand of the goods (Baldus et al., 2015). It has conclusively been revealed that a higher level of engagement occurs when clients involvement in an innovative process of the company, and co-create value for the organization by supplying product/service feedback, improvements, reinforcing the brand or promotions of the company, etc.... Ultimately, at the top level, there is a real engagement between the client, and the company, or the brand. (Zhang et al., 2017). 
Table 2. Conceptualization of customer engagement

\begin{tabular}{|c|c|c|}
\hline Concept & Writers & Description \\
\hline "Customer engagement." & "(Brodie et al., 2011)" & $\begin{array}{l}\text { "A psychological state that occurs by virtue of interactive, } \\
\text { co-creative customer experiences } \\
\text { with a focal agent/object (e.g. a brand) in service } \\
\text { relationships." }\end{array}$ \\
\hline "Customer engagement." & $\begin{array}{l}\text { "(Pansari and Kumar, } \\
\text { 2017)" }\end{array}$ & $\begin{array}{l}\text { "The mechanics of a customer's value addition to the firm, } \\
\text { either through direct or/and } \\
\text { indirect contribution." }\end{array}$ \\
\hline "Customer engagement." & "(Vivek et al., 2012)" & $\begin{array}{l}\text { "The intensity of an individual's participation in and } \\
\text { connection with an organization's offerings and/or } \\
\text { organizational activities, which either the customer or the } \\
\text { organization initiate." }\end{array}$ \\
\hline $\begin{array}{l}\text { "Positively/negatively } \\
\text { valenced } \\
\text { consumer engagement" }\end{array}$ & “(Bowden et al., 2017)" & $\begin{array}{l}\text { "a consumer's positively valenced cognitive, emotional, and } \\
\text { behavioral investments during or related to interactions with } \\
\text { focal objects or agents" "a consumer's negatively valenced } \\
\text { cognitive, emotional, and behavioral investments during or } \\
\text { related to interactions with focal objects or agents." }\end{array}$ \\
\hline $\begin{array}{l}\text { "Customer engagement } \\
\text { behaviors." }\end{array}$ & $\begin{array}{l}\text { "(Van Doorn et al., } \\
2010) "\end{array}$ & $\begin{array}{l}\text { "Customers' behavioral manifestation toward a brand or } \\
\text { firm, beyond purchase, resulting from motivational drivers." }\end{array}$ \\
\hline $\begin{array}{l}\text { "Customer engagement } \\
\text { behaviors." }\end{array}$ & $\begin{array}{l}\text { "(Jaakkola and } \\
\text { Alexander, 2014)" }\end{array}$ & $\begin{array}{l}\text { "Customers make voluntary resource contributions that } \\
\text { have a brand or firm focus but go beyond what is } \\
\text { fundamental to transactions, occur in interactions between } \\
\text { the focal object and/or other actors, and result from } \\
\text { motivational drivers." }\end{array}$ \\
\hline $\begin{array}{l}\text { "Customer } \\
\text { engagement." }\end{array}$ & $\begin{array}{l}\text { "(Hollebeek et al., } \\
2014) "\end{array}$ & $\begin{array}{l}\text { "A consumer's positively valence brand-related cognitive, } \\
\text { emotional, and behavioral activity during or related to focal } \\
\text { consumer/brand interactions." }\end{array}$ \\
\hline "Engagement" & “(Bowden, 2009)" & $\begin{array}{l}\text { "A psychological process that models the underlying } \\
\text { mechanisms by which customer loyalty forms for new } \\
\text { customers of a service brand as well as the mechanisms by } \\
\text { which loyalty may be maintained for repeat purchase } \\
\text { customers of a service brand." }\end{array}$ \\
\hline $\begin{array}{l}\text { "Online brand community } \\
\text { Engagement" }\end{array}$ & "(Wirtz et al., 2013)" & $\begin{array}{l}\text { "The consumer's intrinsic motivation to interact and } \\
\text { cooperate with community members." }\end{array}$ \\
\hline "Online engagement." & $\begin{array}{l}\text { "(Mollen and Wilson, } \\
2010) "\end{array}$ & $\begin{array}{l}\text { "A cognitive and affective commitment to an active } \\
\text { relationship with the brand as personified by the website or } \\
\text { other computer-mediated entities designed to communicate } \\
\text { brand value." }\end{array}$ \\
\hline
\end{tabular}


Table 3. Different types of CE variables according to previous studies

\begin{tabular}{l|l|l|l|l}
\hline Study & $\begin{array}{l}\text { Type of } \\
\text { firm }\end{array}$ & Type of variable & $\begin{array}{l}\text { Conceptual/ } \\
\text { Empirical }\end{array}$ & Definition \\
\hline $\begin{array}{l}\text { (Bowden, } \\
\text { 2009) }\end{array}$ & B2C & $\begin{array}{l}\text { Attitude and } \\
\text { behavior-based }\end{array}$ & Conceptual & $\begin{array}{l}\text { "A psychological process that models underlying } \\
\text { mechanisms by which customer loyalty is formed } \\
\text { for new customers as well as the mechanisms by } \\
\text { which loyalty may be maintained for } \\
\text { repeat-purchase customers of a service brand." }\end{array}$ \\
\hline $\begin{array}{l}\text { (Van Doorn } \\
\text { et al., 2010) }\end{array}$ & B2C & Behavior-based & Conceptual & $\begin{array}{l}\text { "Customers' behavioral manifestation toward a } \\
\text { brand or firm, beyond purchase, resulting from } \\
\text { motivational drivers such as word-of-mouth } \\
\text { activity, recommendations, helping other } \\
\text { customers, blogging, writing reviews." }\end{array}$ \\
\hline $\begin{array}{l}\text { (Brodie et } \\
\text { al., 2011) }\end{array}$ & B2C & Attitude-based & Conceptual & $\begin{array}{l}\text { "A psychological state that occurs by virtue of } \\
\text { interactive, co-creative customer experiences with } \\
\text { a focal agent/ object (e.g., a brand) in focal service } \\
\text { relationships." }\end{array}$ \\
\hline $\begin{array}{l}\text { (Vivek et } \\
\text { al., 2012) }\end{array}$ & B2C & $\begin{array}{l}\text { Attitude and } \\
\text { behavior-based }\end{array}$ & Conceptual & $\begin{array}{l}\text { "The intensity of an individual's participation and } \\
\text { connection with the organization's offerings and } \\
\text { activities initiated by either the customer or } \\
\text { organization." }\end{array}$ \\
\hline $\begin{array}{l}\text { (Pansari } \\
\text { and Kumar, } \\
\text { 2017) }\end{array}$ & $\begin{array}{l}\text { B2B and } \\
\text { B2C }\end{array}$ & $\begin{array}{l}\text { Attitude and } \\
\text { behavior-based }\end{array}$ & Conceptual & $\begin{array}{l}\text { "The mechanics of a customer's value addition to } \\
\text { the firm, either through direct or/and indirect } \\
\text { contribution." }\end{array}$ \\
\hline
\end{tabular}

\subsection{Value Co-creation}

Although the various approaches Skålén et al. (2015) have formulated described the value co-creation concept in their terms, value co-creation is established in service-dominant reasoning. Previous research findings (Vargo and Lusch, 2008 , 2014) concerning logic (S-D), found that it is clients who co-create value. Therefore, the company cannot provide value but instead supply propositions of value. Recently, researches stipulates three initial integrative processes "Service-dominant (S-D) logic" to find out the whether client engagement is a proactive contributor to brand interactions: client engagement framework, integration of client resource and knowledge learning or sharing (Hollebeek et al., 2016). Co-creation of value is defined as one of the three advantages of client engagement (client interpersonal operant, resource co-creation, and expansion of resource), which may be applied to client-management relation.

\subsection{Community Engagement}

In this decade, the academics Baldus et al. (2015) focused on studying the concept of client engagement. Depending on extant studies, their research created a construct of client engagement as a cognitive state that springs during interaction and co-creation of the client's experience with other entities within a particular exchange of service along with a pivot object, which is demonstrated in a positive valence behavior, consisting of active and consistent interactions (Brodie et al., 2011; Van Doorn et al., 2010; Zhang et al., 2017).

For surveys such as those conducted by Dessart et al. (2015) the notion of engagement as applied to the online study of community brands, the locus of engagement was mostly brands. However, numerous studies shed light on the importance of analysing community engagement by taking into consideration the objects of engagement i.e. community brand and members of the community (Baldus et al., 2015; Brodie et al., 2013).

Engagement, which differs from the intensity of usage (Simon et al., 2016) exhibits an individual's intention to actively/voluntarily participate, and to create value for oneself and for others. High levels of positive engagement have been linked to optimum behavior for clients like loyalty and commitment by many studies (Brodie et al., 2011; Mollen and Wilson, 2010; Schamari and Schaefers, 2015). Instead of considering engagement as an exterior factor, scholars indicate that engagement of the client emanates from recurrent and pleasurable interactions between clients and objects of engagement, e.g., brands and communities (Brodie et al., 2013; Hollebeek et al., 2014; Mollen and Wilson, 2010; Van Doorn et al., 2010). 


\section{Exploratory Evidence}

This exploratory research aims to identify the research gap, conceptualize a design model, and formulate a research hypothesis consisting of (A) analysis of secondary data on the ARADO online community members' profiles, and (B) qualitative Research with concerned parties, in-depth interviews with ARADO community members to explore the gap between their online experiences and expectations with Arado service (Arab Administrative Development Organization [ARADO], 2020).

\section{Research Gap}

The theory of service ecosystem provides a central paradigm that can be used to associate the consumer experience concepts co-created through interactions. Furthermore, engagement (as a result of customer experience assessment) and WOM intention (as a display of the behavior of dynamically engaged clients) can lead to continued value co-creation in network/online brand communities. By enhancing consumer voices and providing information and benefit, brand communities create value. This research seeks to identify different fields in which the value co-creation through customer experience and customer engagement within the online community's discourse occur, and concurrently point out the foundations of the discussions and its main topics.

Evaluation of the relationships between customer experience and customer engagement increases existing knowledge in three ways. Firstly, by breaking down the CE and empirically examining the corresponding relationship of the CX dimensions and the possible eWOM behaviors and purchase intentions in online settings, and how the CE dimensions change with the appropriate eWOM behaviors. Secondly, by integrating the eWOM concept to include opinions in the brick and mortar word of mouth (WOM) concept. Thirdly by illustrating the behavior of the users in general social networking sites and brand-related sites, such as admin sites as opposed to previous studies that deepened in the general field of social networking, such as Facebook and Instagram, where social interactions and networking are the primary reasons for involvement in eWOM.

Furthermore, this research proposes to evaluate relationships between customer engagement and purchase intentions; extensive research has already been done on the positive and direct connections between loyalty and customer purchase intention. It has conclusively been shown that when the percentage of customer engagement increases, and the rate of customer loyalty increases, and this could potentially lead to a brand's success.

Therefore, these relationships between customer experience, engagement, purchase intention, need to be empirically investigated. In response to this gap, this research aims to examine the online associations and proposes CX dimensions (Pragmatic, Hedonic, Sociable, and Usability) as an essential consequence of the customer experience that promotes purchase intention. This will be bridged by the conceptual framework that will be articulated in detail in a subsequent study.

\section{Research Aims}

This aims of this research is to;

1) help online businesses to maximize their benefit from the virtual community;

2) assist companies identify the most important factors affecting customers' purchase intentions;

4) aide organizations to fully understand the domain of online brand community to address the growing challenges with the growth and development of the internet is constantly changing;

5) identify the relationships between online customer experience, customer engagement and purchase intentions under study.

\section{The Proposed Conceptual Model}

The conceptual model proposed for this research seeks to bridge the gap in section (4). The proposed model is based on triangulation between the review of literature, the analysis of secondary information and qualitative exploratory This research, as well as the deductive reasoning of the researcher, to advances this case to further into, is promising and able to contribute to theoretical development and political implications of the subject.

\subsection{Objectives of the Model}

This Research aims to achieve the following objectives:

1) gain a better understanding of how customer experience evolves into customer engagement, paving the way to customer purchase intention (CPI) in the Arab OBCs.

2) Identify the most critical factors affecting purchase intention.

3) Propose methods to influence the purchase intention of online communities of Arab customers. 
4) Explore the role of customer engagement (CE) as a mediating variable on the pathway between customer experience and purchase intention (PI).

\subsection{Anticipated Contribution of the Model}

According to the main argument in the literature review in this study, purchase intention (PI) is affected by many factors that may be linked to the company or marketing programs or product quality or elements belonging to consumer personality and his experience. Therefore, this research study aims to identify the most imperative factors affecting PI, in online brand community (OBC). The study's research questions are:

1) RQ 1 What is the relationship between customer experience and customer engagement?

2) RQ 2 What is the relationship between customer engagement and purchase intention?

3) RQ 3 What is the relationship between customer experience and purchase intention?

4) RQ 4 Is there an impact of customer engagement (CE) on the relationship between customer experience and purchase intention?

\subsection{Scope of the Model}

The research will conducted be within the following boundaries:

1) The research will focus only on investigating two factors: (Customer experience, Customer engagement affecting Purchase intention) in OBC; other factors that can affect purchase intention will not be investigated.

2) The research will focus exclusively on Arab internet users who use ARADO Facebook platform.

3) Only online interactions will be analyzed. Online cannot be segregated and can communicate and/or affect one another than offline experiences. Ultimately, studies are needed to analyze together the offline experiences and online perceptions of customers.

\subsection{Structure and Main Argument of the Model and Its hypothesis}

\subsubsection{Customer Experience (CX) and Customer Engagement (CE)}

Over the last ten years, research on customer engagement (CE) has emerged in literature with a strong disagreement with respect to components and conceptualization. Engagement of the Client in marketing fields was considered a unidimensional or multidimensional construct that involved affective, cognitive, or behavioral qualities of relationships between a client and a company or a brand (Hollebeek, 2011). Recently, in vitro studies have shown that the multidimensional perspective has begun infusing the literature with emphasis on the behavioral aspect (e.g., Hollebeek, 2011; Mollen and Wilson, 2010; Patterson et al., 2006; Vivek et al., 2012).

Customer engagement behavior denotes a client's behavioral display (concerning a business, brand, or other clients) beyond buying. It includes review writing, blogging, support of different clients, referrals provision, enhancement of the positive experience through positive word-of-mouth (WOM), endorsements for a product or brand, and co-creation of values for the company or engagement with the preferred brand name (Brakus et al., 2009; Brodie et al., 2011; Hoyer et al., 2010; Nambisan and Nambisan, 2008; Van Doorn et al., 2010).

Previous studies have defined interaction with the client as a mental condition, arising from the cognitive and emotional affiliation with a brand in a specific situation (Hollebeek et al., 2014; Mollen and Wilson, 2010; Vivek et al., 2014).

Engagement of the Client ought to be displayed in behavioral cognitive and emotional interplay with a business or a brand. Recent evidence that has described Customer Engagement as a quick psychic process, which is founded on a reality of the client's interactive co-creative experience in a defined set of conditions, and with a specific object concurs with this perspective (Brodie et al., 2011). Along with this viewpoint, this analysis posits that a genuinely engaged client must depict attitudinal and behavioral exhibitions.

Several research studies that investigate psychic engagement involve client stance. Such research could have paybacks for the company (Prentice et al., 2018). The attitudinal perspective depicts a mental state with a client's elevated engagement, interactions with companies, involvement, belongingness, and includes affective and cognitive components and is denoted as attitude engagement of the client. The behavioral aspect represents a behavioral display, which extends beyond dealings arising from a person's emotion/cognition which Porter et al., (2011) referred to as client behavioral engagement. The behavior of the individual is highly regulated by intention and is highly steered by attitude (Fishbein and Ajzen, 1977). Several studies on the relationship between attitude, intention and behavior have yielded conflicting results (Dong et al., 2010; Han et al., 2008; Li et al., 2009). Client attitudinal engagement functions as the psychic foundation of client behavioral engagement; therefore, it has an impact on behaviors impacting engagement. Accordingly, the following hypothesis were formulated: 
H1: Customers' perception of online experience - (a) pragmatic, (b) hedonic, (c) sociability, (d) usability - is positively related to customer engagement.

\subsubsection{Customer Engagement and Purchase Intention}

Online brand communities serve as targets for clients and company's engagement, and for strengthening the ties between the company and the client, thereby boosting profit and increasing client loyalty.

Earlier research illustrated that indicators of customer engagement have a direct impact on customer loyalty and purchase (Brodie et al., 2011; Gummerus et al., 2012; Hollebeek, 2011; Prentice et al., 2018; Vivek et al., 2012). The client engagement level affects the client's loyalty level and ultimately, the success of the brand (So et al., 2014).

The intent of the client to engage with a brand community can be translated into an intention to buy from this brand. Therefore, client behavioral engagement displays client behavior by toward a brand/company, that goes beyond the stage of purchasing, and is an outcome of the client's interaction and experience with the brand, or with other clients. Through this interactive process, clients establish secure connections with the communities related to the brand. Such ties prompt clients to continue to buy services or products related to the brand (Prentice et al., 2018). Engagement behavior streamlines and clarifies clients' paths on the continuum of belief, attitude, and behavior (Vivek et al., 2012). It also impacts on client loyalty towards the business and promotes repurchase behavior (Harrigan et al., 2017; So et al., 2014; Van Doorn et al., 2010).

Additionally, the following hypothesis was formulated:

H2: Customer engagement dimensions (attitudinal and behavioral) are positively related to customer purchasing intention.

\subsubsection{Online Community Experience (OCX)}

Customer experience is a set of impressions, experiences, and attitudes that evolve during the whole cycle of decision making and the consumption chain involving an interconnected series of encounters, leading to cognitive, emotional, sensory, and behavioral reactions with individuals, objects, processes, and the environment. Due to various research viewpoints, researchers have not come to a consensus regarding customer experience dimensions. The present research aims to investigate the customer experience of online brand communities that is outside the transactional sense, (the paradigm may be more consistent with the research context) Nambisan and Watt, (2011) i.e., Social media, such as Facebook as an online community of brands, by concentrating on user's engagement experiences. In other words, it is the experience that the customer can gain from specific online brand platforms, which may be expressed in terms of these concepts: (Pragmatic, Hedonic, Sociability and Usability) as follows:

Firstly, a pragmatic dimension of OCX has been defined as the utilitarian value the customer experiences from interactions in the online product platforms. Traditionally, Hoffman and Novak, (1996) refer to this concept as objectives behavior that reflects if the customer finds an experience in the online platform beneficial (Mathwick et al., 2001).

Secondly, a hedonic dimension of OCX is defined as the intrinsic values the consumer develops from interactions with the online brand platform. The concept reflects the pleasure, and the delight customer feels when he/she focuses on the brand. The brand provides an environment from which the customer drives delight and obtains positively hedonic experiences (Mummalaneni, 2005; Voss et al., 2003). However, an interaction may lead to boredom and might decrease the level of hedonic experiences (Honeycutt, 2005; Mummalaneni, 2005).

Thirdly, a sociability dimension of OCX is defined as the social experience that the customer can acquire from interaction with the brand platforms community. This concept encompasses a customer's perception of the friendliness of the community participants. In other words, it alludes to the social environment that results from the community of customers, which may lead to a higher level of social experience that will eventually create healthy relationships and networking (Preece and Preece 2000). Contrarily, the social environment that results from the community of customers may lead to a lower level of social experience, for instance an ill-mannered community weaken relationships and networking (Honeycutt, 2005).

Finally, a usability dimension of OCX is defined as the customers' experience when a customer joins online platforms and uses the environment. This concept entails flexibility and familiarity with the technology's features. The effortlessness of use has a direct and positive impact on the degree of interest in the platforms (Nielsen, 2000; Preece and Preece, 2000; Shneiderman and Plaisant, 2004). Conversely, the difficulty of use has a direct and negative impact on the degree of interest in the platforms (Nielsen, 2000; Venkatesh and Agarwal, 2006). Consequently, the following hypothesis was formulated:

H3: Customers' perception of online experience - (a) pragmatic, (b) hedonic, (c) sociability, (d) usability - is positively 
related to their purchase intention.

\subsubsection{The Mediating Role of Customer Engagement (CE)}

Compared to conventional WOM, E-WOM is a novel internet medium, which transcends the limits of the traditional forms of verbal communication (López and Sicilia, 2014). It is considered a mechanism by which individuals (submissions) influence other people (submitters) and bypass other stimuli (e.g., linguistic symbols) via E-WOM transmission on social networking sites (Kotler and Gertner, 2011). It is has been empirically shown that dedicated customers have an increased their interest in a company's products/services, and talk to others about those products/services (Carvalho and Fernandes, 2018). Customers are convinced through CE to defend the company (Vivek et al., 2014). Furthermore, consumers strive to improve a company's image by exchanging resources with others (Leventhal et al., 2014). Customer-to-customer experiences have been encouraged by advances in technology and social media growth. Committed consumers are more inspired and willing to support the business. The CE also promotes the customer to suggest services to others (Algharabat et al., 2018). Customers who are dedicated are more knowledgeable about the goods and want to pass on that knowledge. A company's products/services are therefore better positioned to be referred to others (Islam and Rahman 2016). Researchers have proposed that CE and E-WOM are positively related (Yu et al., 2020). CE and co-creation literature has broadened the horizons of the feedback concept. Feedback is no longer confined to complaining; instead, it has expanded to assess customer needs or wants and the level of customer satisfaction (Voss et al. 2004). Feedback is an aspect of CE action (Van Doorn et al., 2010). Scholars have widely recognized the willingness of organizations or brands to provide input to.....and the rigorous influence of the purchase intentions of engaged customers (Harmeling et al., 2017). This leads to the next hypothesis:

H4: customer engagement (CE) has a significant mediating effect on the relationship between customer experience (CX) and Purchase intention (PI).

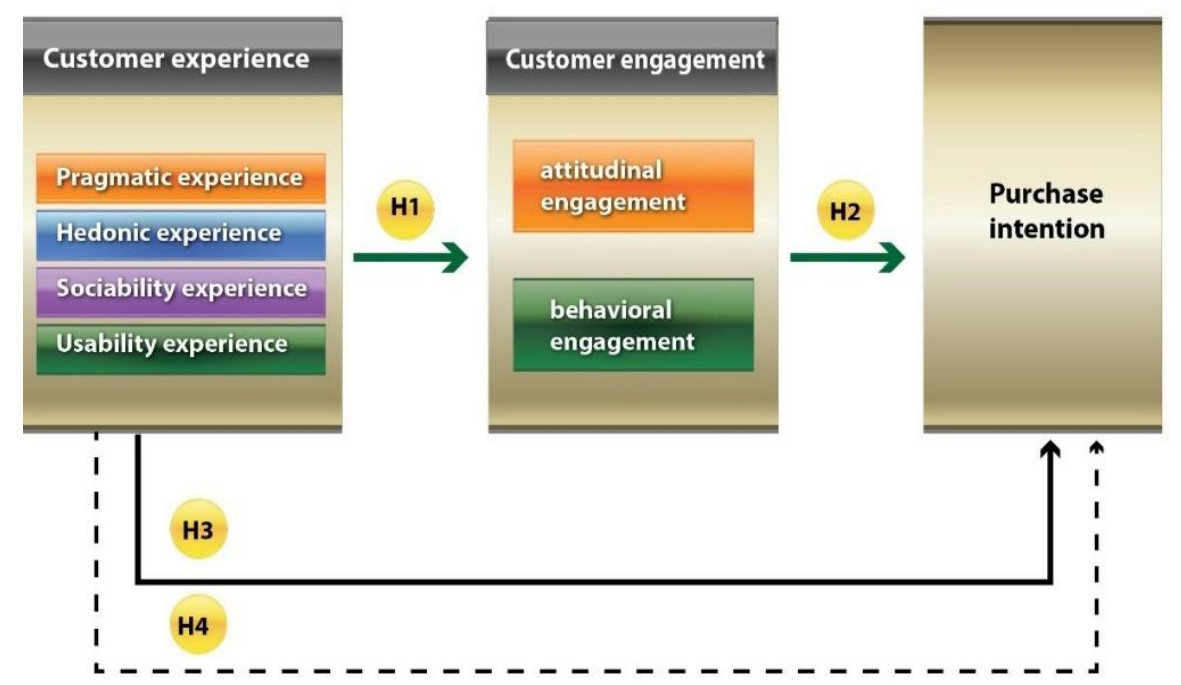

Figure 1. The proposed conceptual Model: $\rightarrow$ Direct relationship $\rightarrow$ Indirect relationship

Source: Made by the researcher

\section{Planned Research Methodology}

The research methodology adopted in this study to investigate the research hypotheses is described below.

\subsection{Research Design}

The design to be employed will be both exploratory and quantitative.

The current study will employ a mixed methodology that will use qualitative and quantitative methods. This was selected for two reasons; firstly, using both methods leads to more confident results. Secondly, the combination of both approaches helps increase the accuracy and clarity of the research problem, as the two approaches are complementary (Malhotra et al., 2010; Creswell and Creswell, 2017).

The current study will therefore be conducted in two phases;

Phase one used a qualitative process to examine the literature and conduct out an exploratory study, through seven thorough online community interviews to ensure that the attributes of customer experiences used in previous studies were valid to Arab Internet users and to identify additional characteristics for online customer experiences. Thus, the 
researcher was able to better describe the research problem and develop hypotheses.

Additionally, the factors affecting purchase intention were reviewed to unearth the variables that could moderate the study relationship, then the exploratory study was conducted; to specify precisely the research problem, to settle on the study variables, its measurement scales and the relationship between them, and finally to develop the research hypotheses (Malhotra et al., 2010).

\subsubsection{Exploratory Research}

The exploratory study involved collecting primary data, which are the data collected from ARADO's online communities. The data were collected to determine whether the online customer experience attributes found in previous literature are relevant in the Arab internet user's environment. Another aim was to determine whether there were other variables under the online customer experience that were not stated in the previous literature, specifically factors that significantly affect purchase intention in online brand community settings. Finally, the data were collected also to help the researcher inform the research hypotheses.

Other than the literature reviews, the following research activities were undertaken to support the formulation of the research problem and hypothesis:

\section{Analysis of secondary data}

The analysis of secondary data from the ARADO Facebook page: ARADO was selected as an online brand community. This is because organizations can improve their reach and customer experience using social media by monitoring and responding to specific activities such as number of user reviews, followers, or likes. (Chahal and Rani, 2017; Grégoire et al.,2015; Newberry, 2019; Seo and Park, 2018).

Investigating the full range of social media activities requires an investigator to examine the social media pages selected by a company, its supporting social media platforms, and the intensity of interactions of users on its' platforms. To understand the potential social media platforms a company can opt to use, social media platforms are categorized into six different types: collaborative projects, content communities, microblogs, social networking, virtual game worlds, and virtual social realms. Among these, content communities, microblogs, and social networking are the main focus of companies (Kaplan and Haenlein, 2010; Stelzner, 2018).

Companies are now investing their resources in content groups, microblogs, and social networking to increase their social media presence and effectively use their social media platform. Companies use these unique social media platforms to support diverse strategic areas, such as market management, innovation, new product development, and customer relations, as well as various activities, such as entertainment, sharing of information, and crowds. (Culnan et al., 2010; Hoffman and Fodor, 2010; Kim and Ko, 2012; Muniz and O'Guinn, 2001; Shen and Bissell, 2013; Simon et al., 2016). This study focuses on a particular type of social media platform i.e Facebook as social networking to evaluate the relationship between customer experience, customer engagement, and purchase-intention in online brand communities. This study identifies various components and capture the online activity of the Facebook page of ARADO which has a diverse community - as an online brand community The page has a total 39780.00 people like from Arab users in 45 countries. (ARADO, 2020).

\section{ARADO's Background}

"The Arab Administrative Development Organization (ARADO) was established in 1961 as a specialized organization of the League of Arab States to shoulder the responsibility of organizational development in the Arab region. As stated in its' establishment agreement, ARADO's mission is to comprehensively contribute to the organizational development in the Arab countries. In its' endeavor to fulfill this mission, ARADO has been and is still making efforts to offer services and programs to governments of 22 member states of ARADO. The scope of ARADO services also extend to include governmental organizations, public enterprise associations and the private sector. This is done at three levels of administrative leadership, namely supervisory, mediatory, and executive leadership." (ARADO, 2020). In order to increase its' brand community and awareness, ARADO published its own Facebook page created on December 21, 2015. ARADO's Facebook insights are shown in figures 2 to 17. 


\section{ARADO Facebook page Insights}

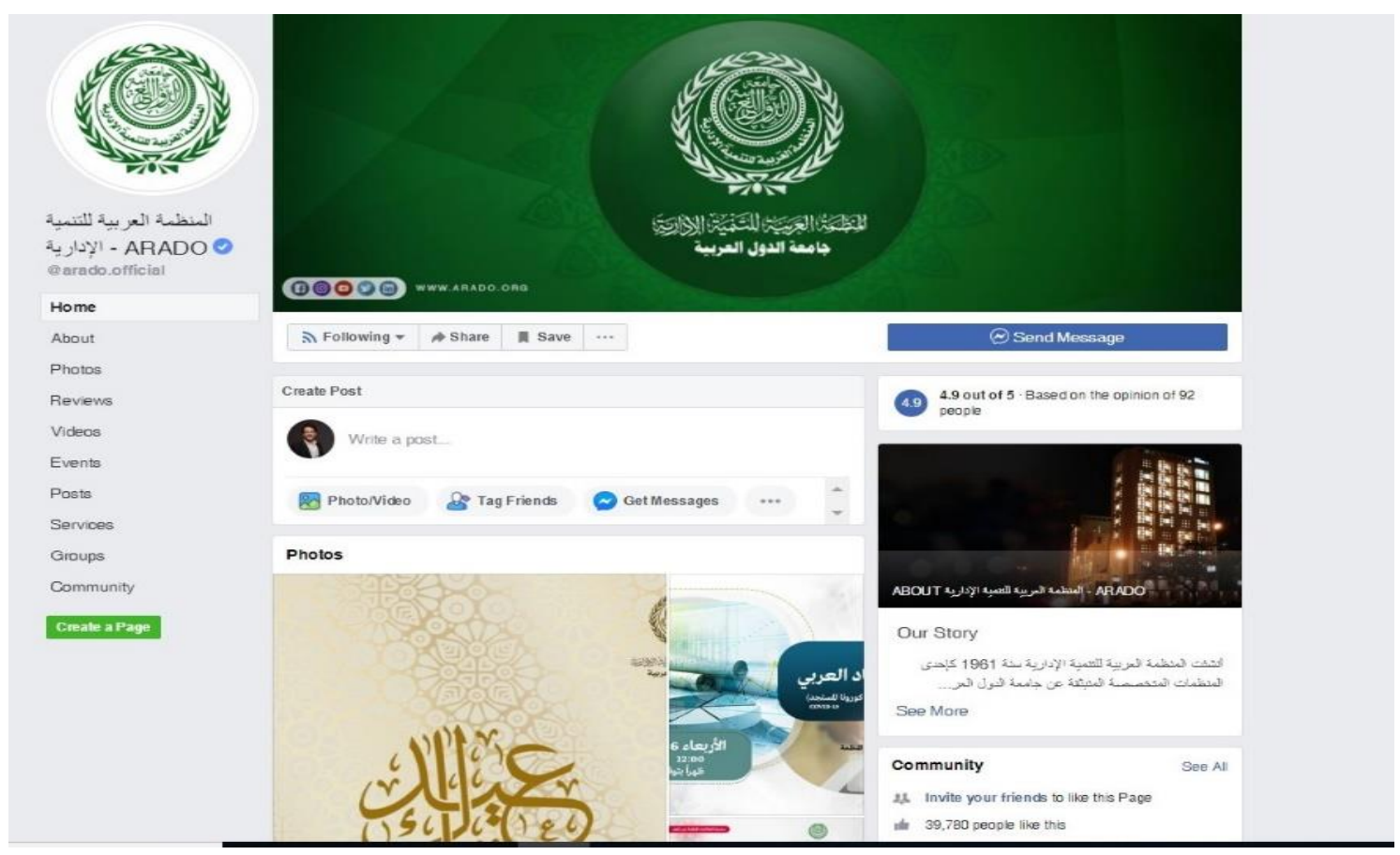

Figure 2. ARADO Facebook page

Source: (ARADO, 2020)

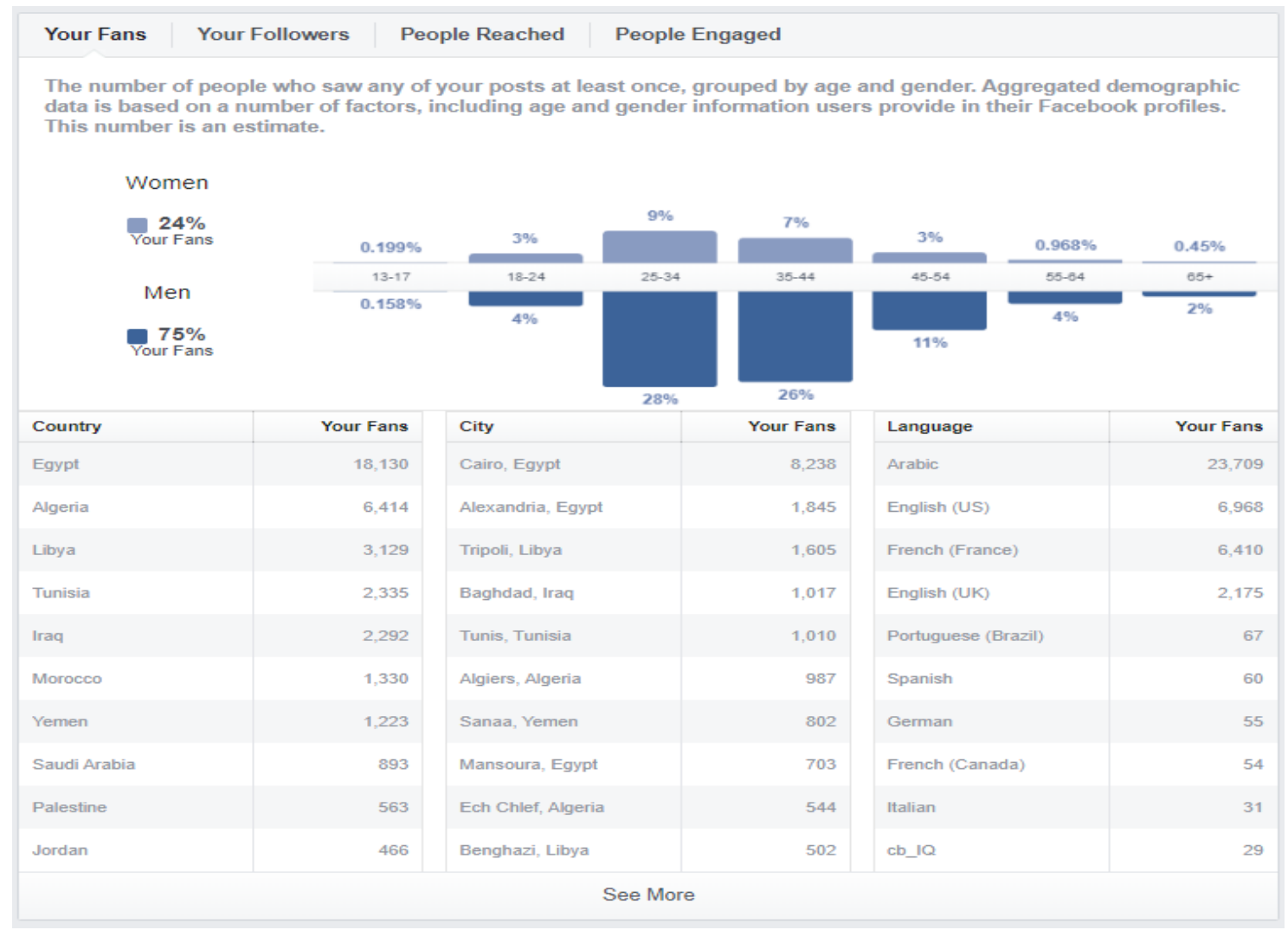

Figure 3. ARADO Facebook page people fans by age and gender

Source: Information Technology Unit (ARADO, 2020) 


\section{People \\ your followers}

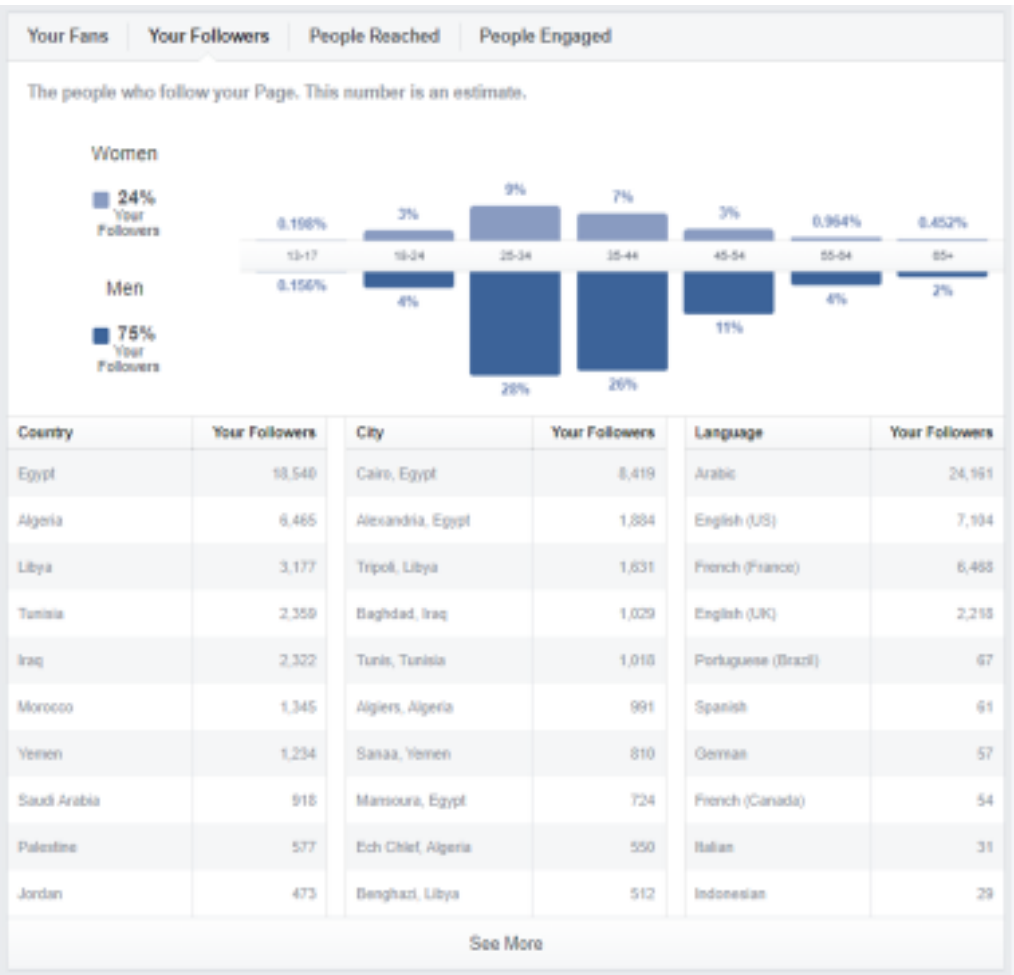

Figure 4. ARADO Facebook page people followers by age and gender

Source: Information Technology Unit (ARADO, 2020)

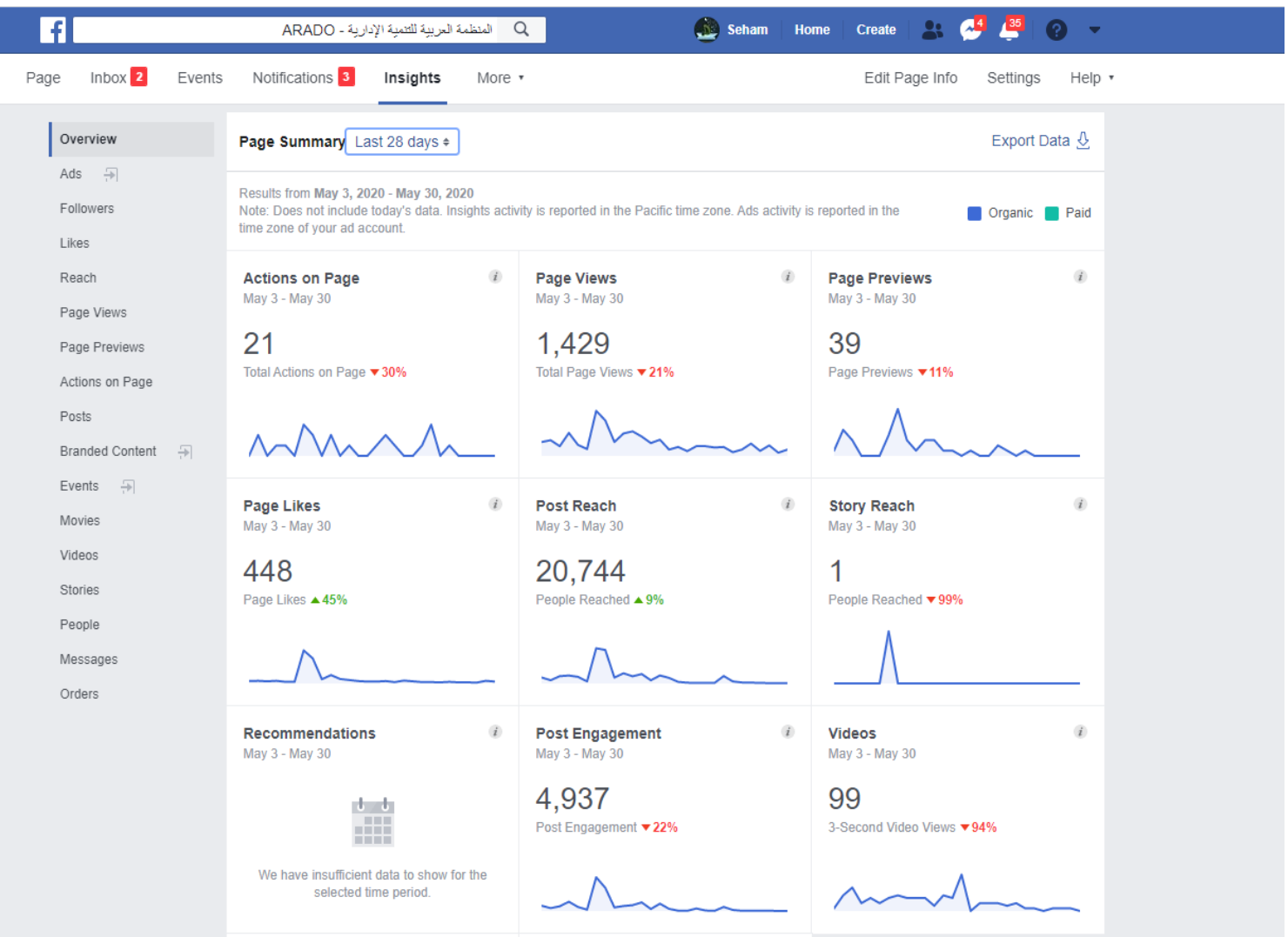

Figure 5. ARADO Facebook page summary total page likes 448 and post engagement 4937.00 members Source: Information Technology Unit (ARADO, 2020) 


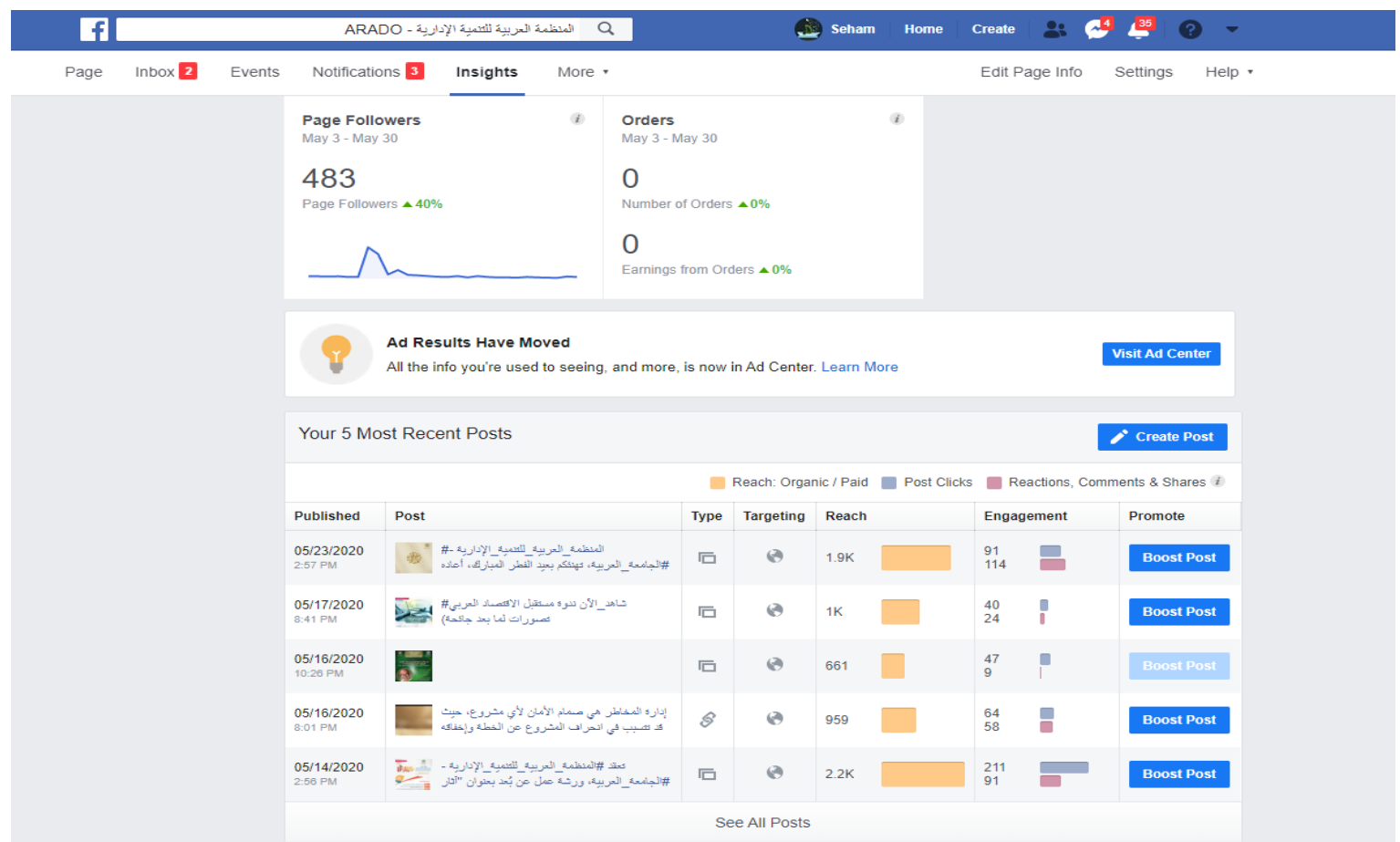

Figure 6. ARADO Facebook page most recent posts Some interaction like (reach and engagement) Source: Information Technology Unit (ARADO, 2020)

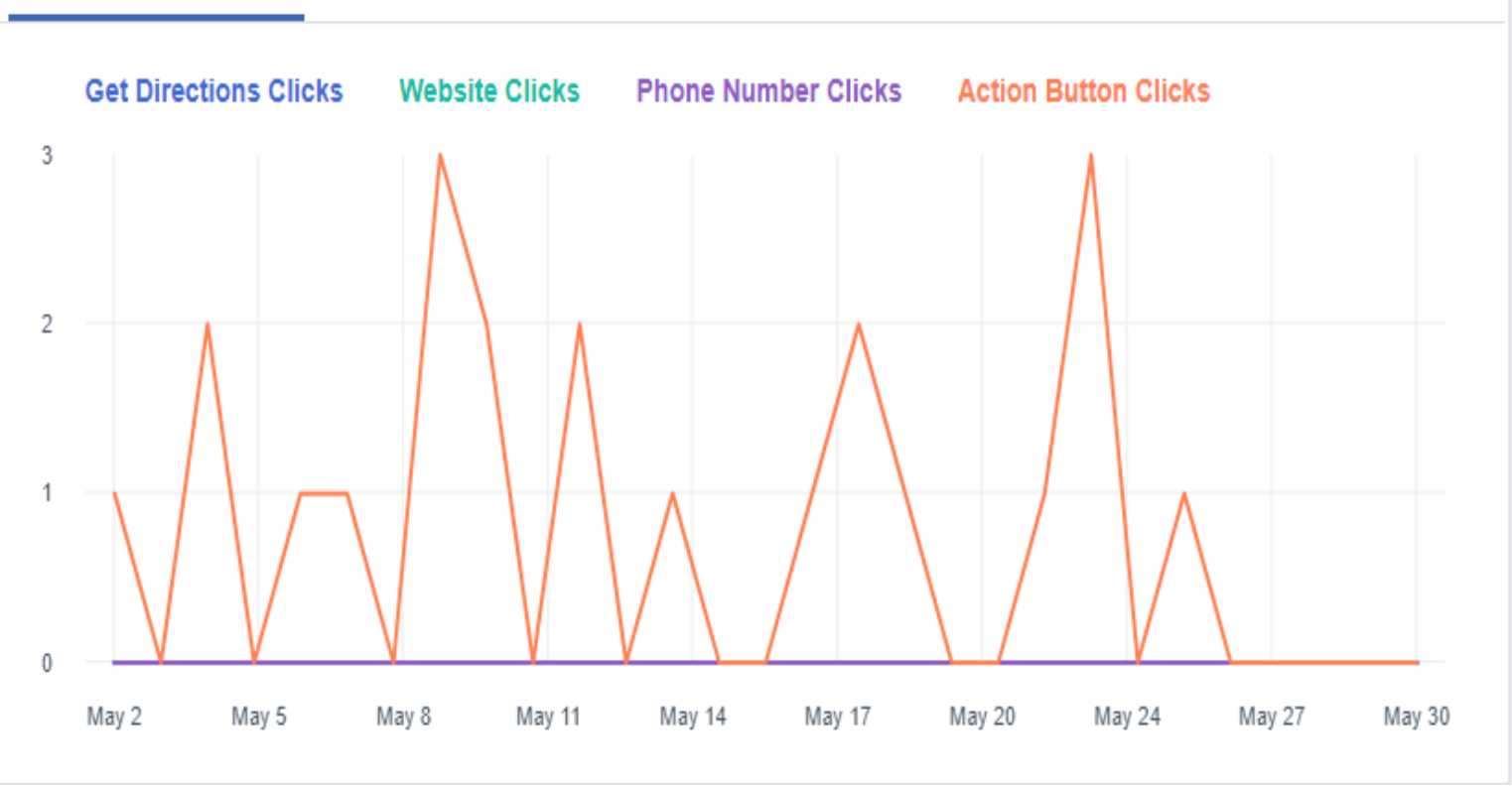

Figure 7. ARADO Facebook page total action on the page Some information (website, phone number clicks) Source: Information Technology Unit (ARADO, 2020) 


\section{Action on page}

People who clicked action button

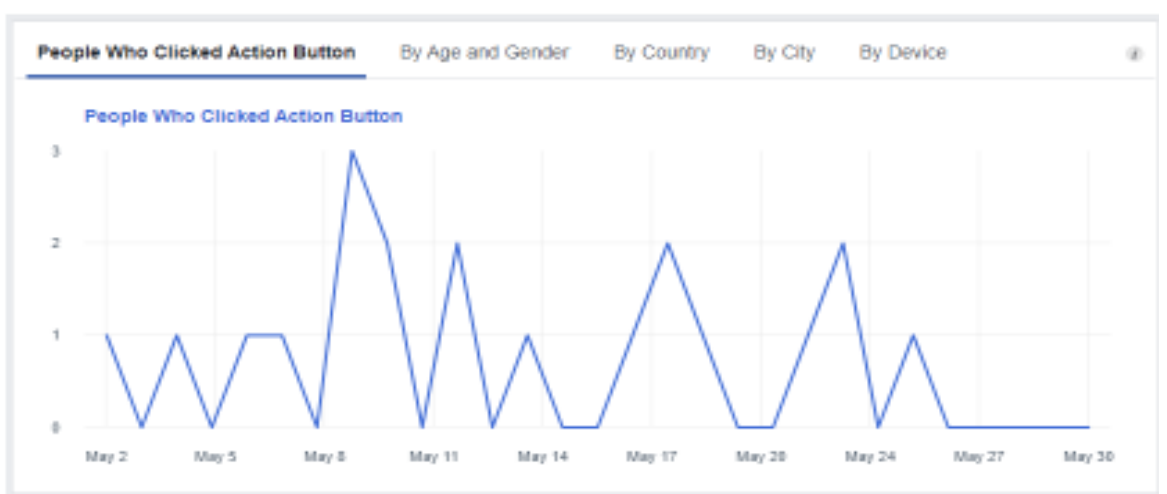

Figure 8. ARADO Facebook page, people who clicked action button

Source: Information Technology Unit (ARADO, 2020)

Page views

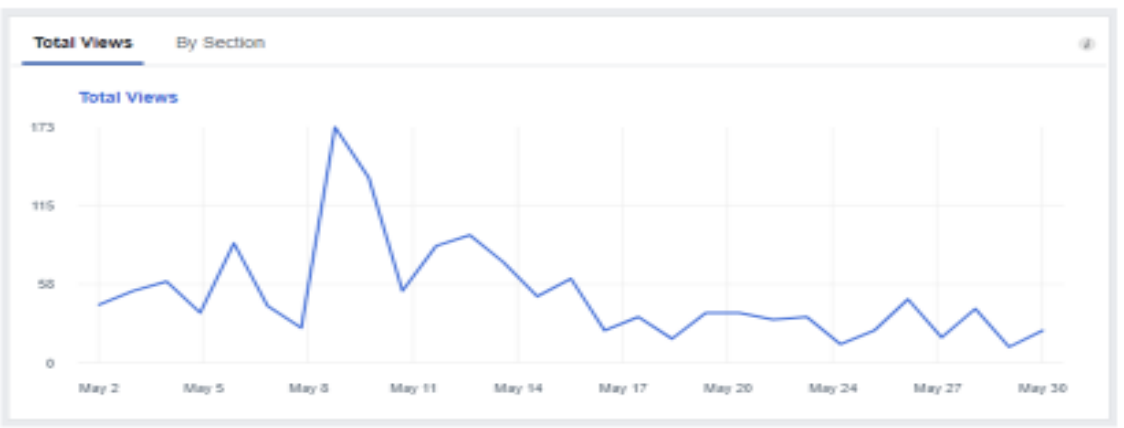

Figure 9. ARADO Facebook page total page people views

Source: Information Technology Unit (ARADO, 2020)

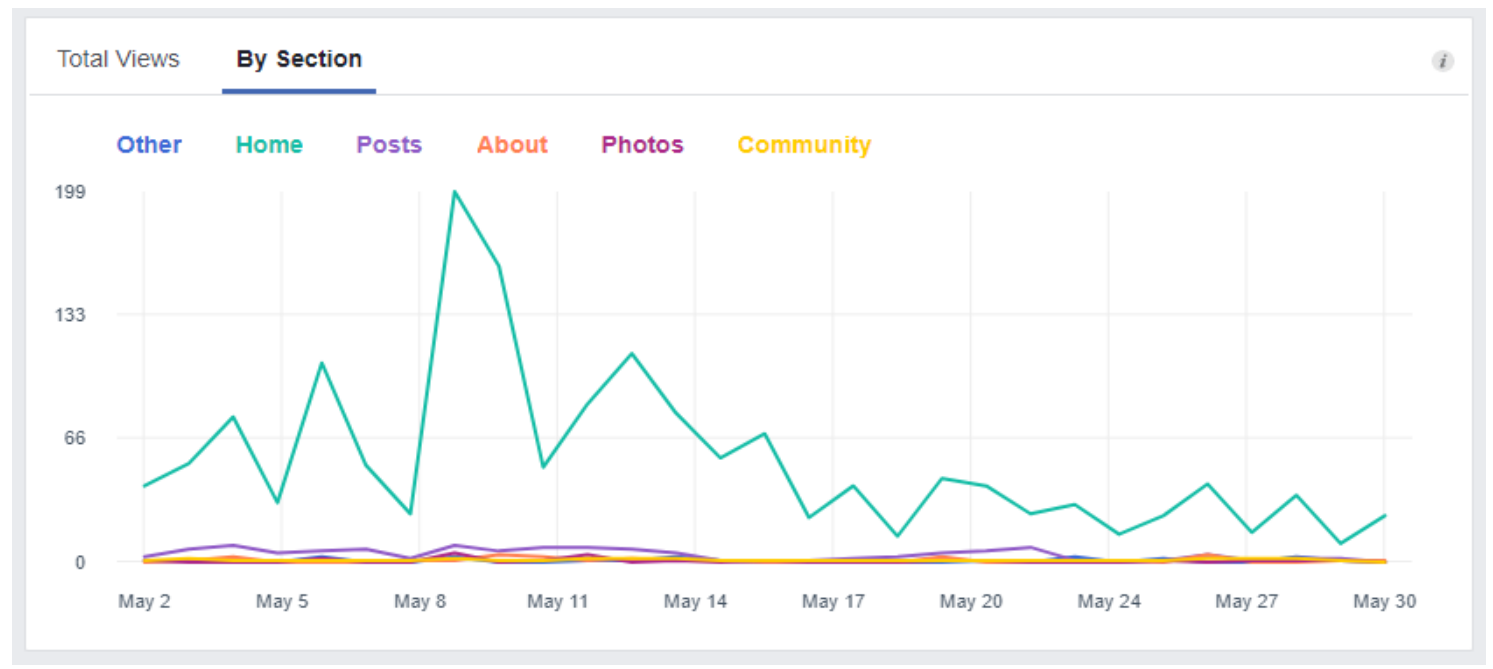

Figure 10. ARADO Facebook page information for specific sections (home page, posts, photos, and community) Source: Information Technology Unit (ARADO, 2020) 
Page views

Top sources

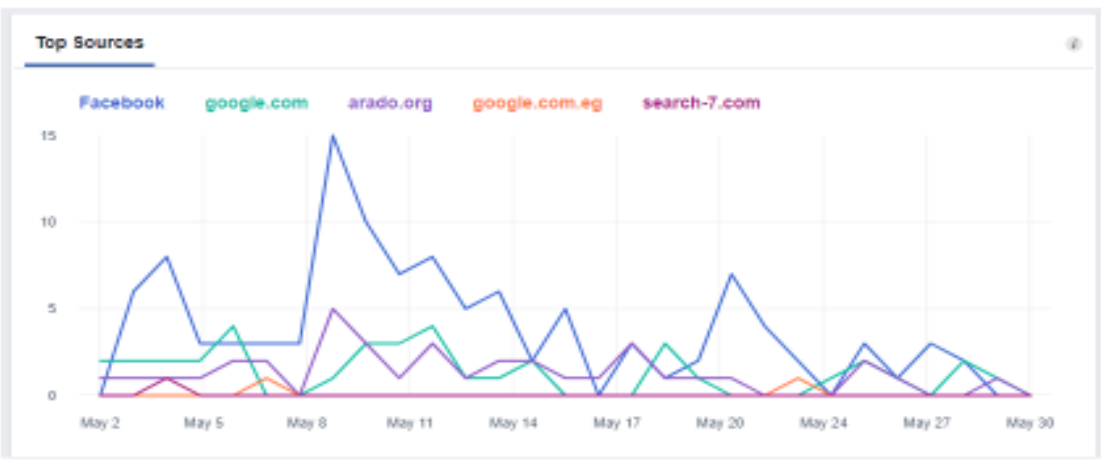

Figure 11. ARADO Facebook page information like (Facebook home, Google, and website)

Source: Information Technology Unit (ARADO, 2020)

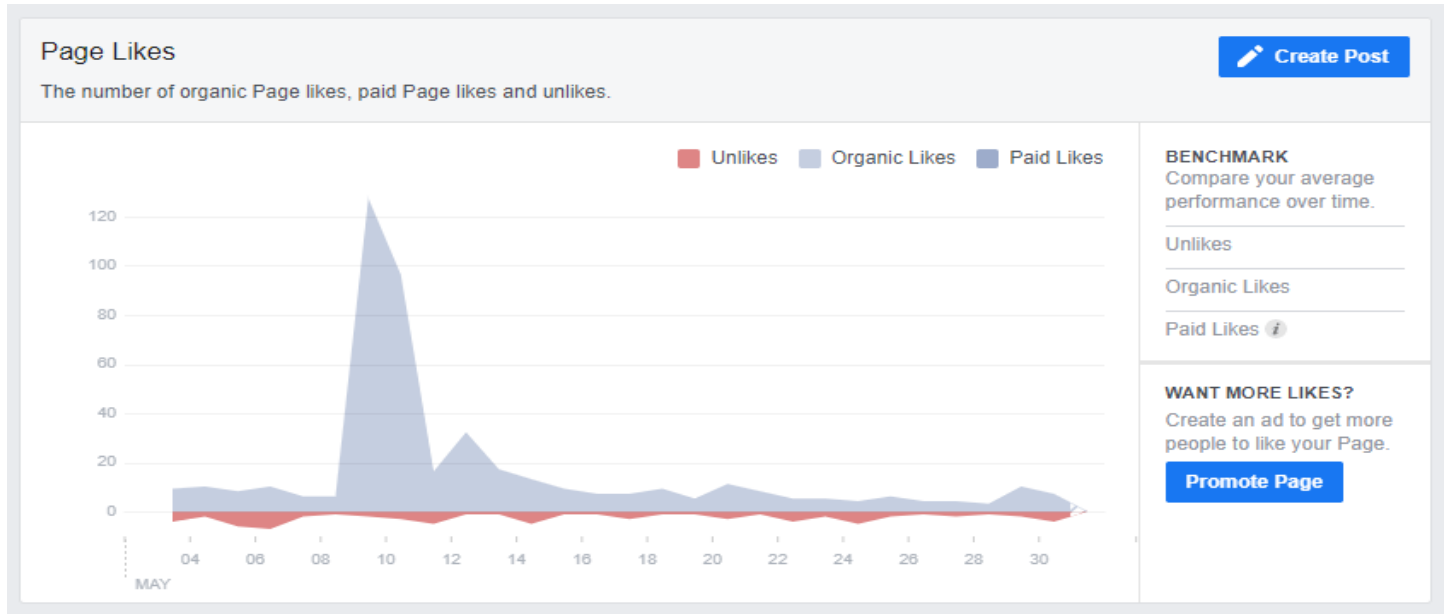

Figure 12. ARADO Facebook page, total page people likes

Source: Information Technology Unit (ARADO, 2020)

Page likes

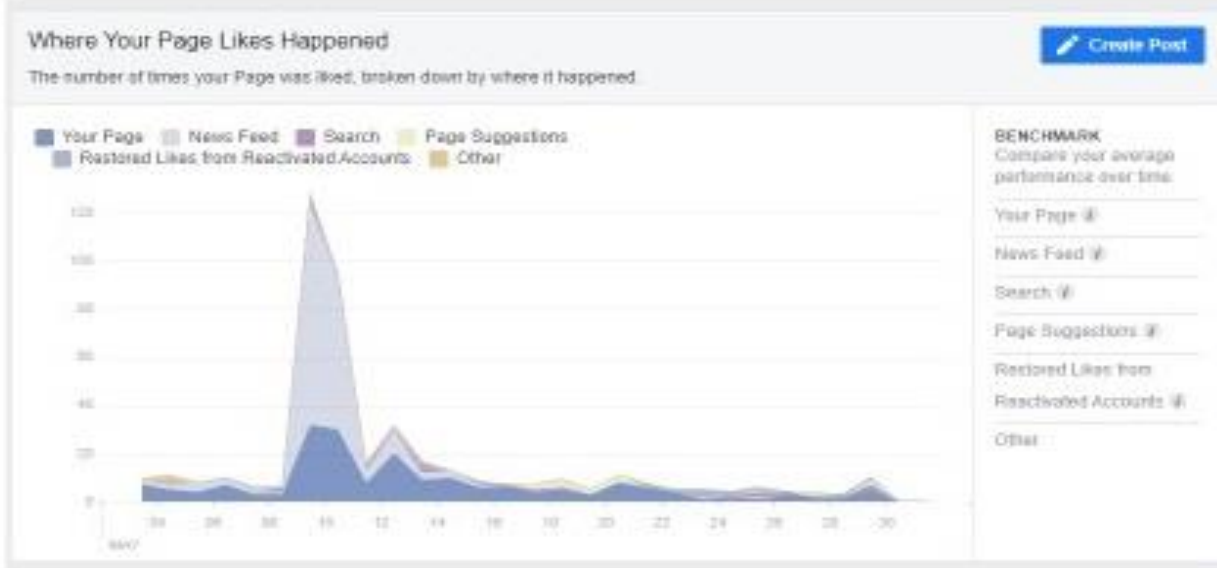

Figure 13. ARADO Facebook page where the action likes by people happened Source: Information Technology Unit (ARADO, 2020) 
Reactions, Comments, Shares and More

These actions will help you reach more people.
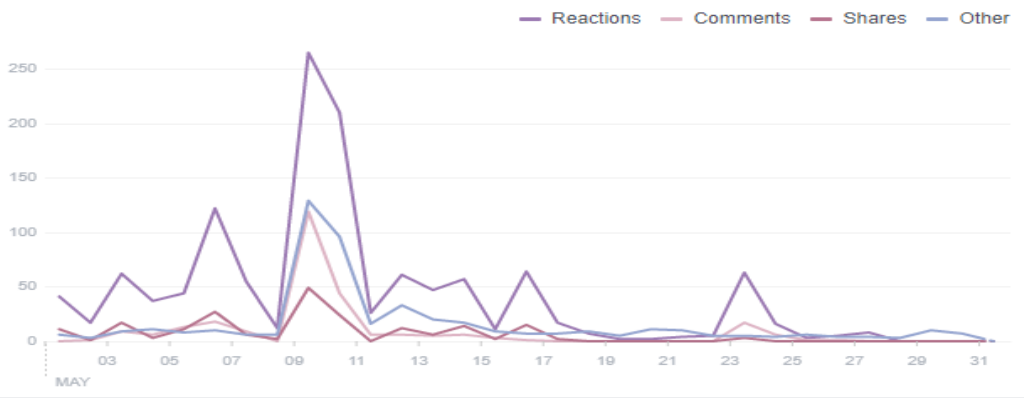

BENCHMARK performance over time. Reactions

Comments

Shares

Other

Figure 14. ARADO Facebook page post people reach information about (like reactions, comments and shares) Source: Information Technology Unit (ARADO, 2020)

\section{ARADO Facebook page people comments}
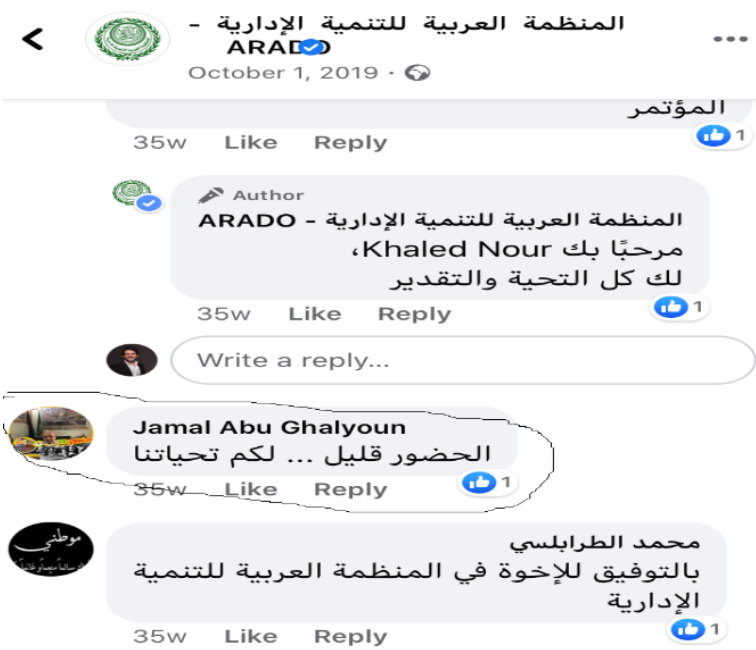

Figure 15. ARADO Facebook page member's comments "The number of audiences is scant"

Source: ARADO Facebook page (ARADO, 2020)

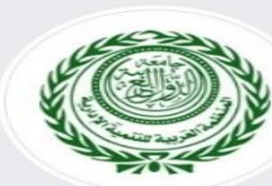

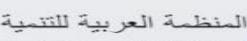

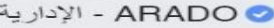

Qarado.oifficial

Home

About

Photos

Reviews

Videos

Events

Posts

Services

Groups

Community

Create a Pags
A Following - $\rightarrow$ share a Save ...

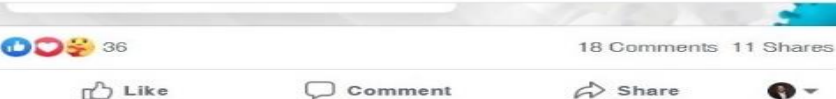

Mast Relevant -

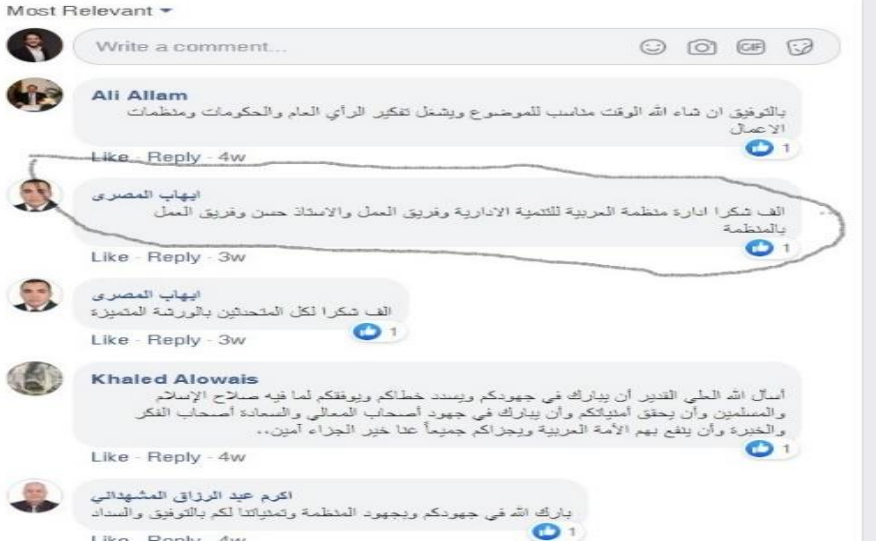

Figure 16. ARADO Facebook page member's comments "Thanks for the top management in ARADO and the team" Source: Facebook page (ARADO, 2020) 


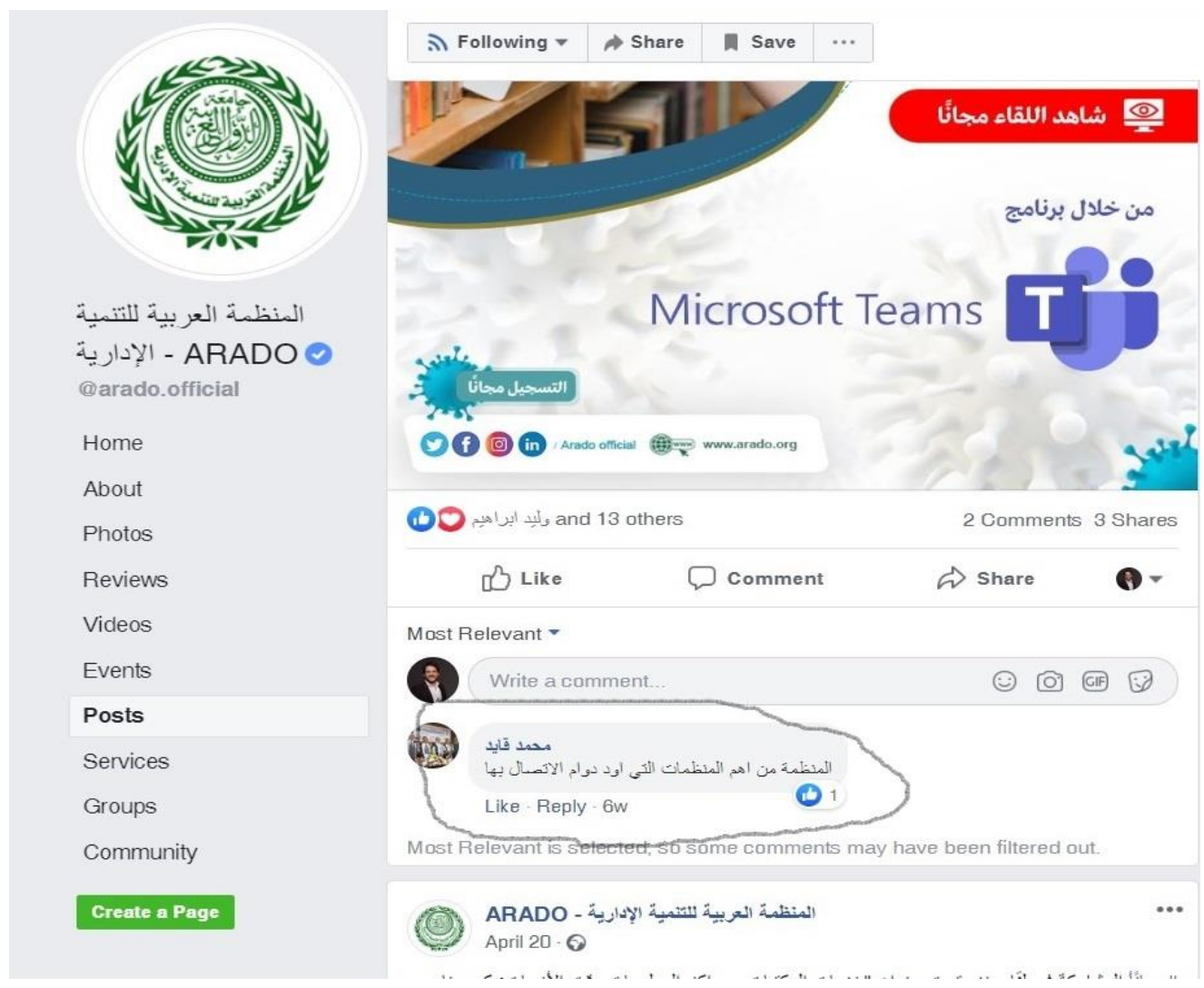

Figure 17. Facebook page member's comments "ARADO is one of the most important organizations that I want to keep in contact with"

Source: ARADO Facebook page (ARADO, 2020)

\section{Qualitative research with concerned parties}

Phase one also conducted seven online community interviews to ensure that the attributes of customer experiences used in previous studies were valid to Arab Internet users and to identify additional characteristics for online customer experiences. Thus, the researcher was able to better define the research problem and develop research hypotheses.

\section{Sampled units}

The researcher conducted interviews with a convenient sample of 7 persons from ARADO's online community; the sample consisted of 7 male participants from United Arab Emirates, Saudi Arabia, Egypt and Palestine. Their ages ranged from 28 - 52. Customer database Source: Quality \& Follow up Unit (ARADO, 2020).

\section{Data collection}

Data were collected through in-depth interviews as this method would provide a detailed understanding of the impact of customer experience on customer engagement and purchase-intention in online brand communities, permit gathering a large amount of information and also provide for clarification (Malhotra et al., 2010). Convenient sampling was that is more suited to for studies was used as the sampling methodology (Malhotra et al., 2010) to identify online members in ARADO's brand community who accepted to participate in the study. The 15-minute interviews were conducted over the telephone.

During the interview, the researcher used the laddering technique to pose questions to respondents. This technique is most suitable methods for exploring the attributes of the online customer experience and its importance among the ARADO's online community members. Additionally, a direct approach was also used in interviewing the respondents after the research aim had been explained (Malhotra el al., 2010).

\section{Results of interviews}

Online customer experience attributes and factors that have a role in online customer experience and purchase intention relationship are summarized below 
1) the pragmatic experience attributes

"The programs and events which were offered by ARADO are known to be accredited locally, nationally and internationally; by hiring foreign speakers for international case studies to exchange knowledge and information; establishing relationships with global institutions and academies for research and development; creating diverse themes and subthemes for events layouts; extending programs and events for more than four days; decreasing fees; and providing more information about the program and activities, these programs provide a sure guarantee of quality prior to making a purchase."

"Sometimes the web/Facebook page or information doesn't show everything", therefore the pragmatic online customer experience attributes will have an influence on purchase-intentions.

2) the hedonic experience attributes

"More interaction; ease of to access the event from any Arab country; I go online when I don't have time or money to travel to attend courses face to face; when I have no time and effort I go online as it is more convenient; when I want to see reviews of thousands of users I go online where I will find all users in one place."

"I can be safe and keep my social distancing during the period of COVID -19."

Thus, the ease of access, the shopping experience, shopping orientation (goal-oriented vs. experiential), as well as the attitudinal and behavioral engagement, all have a role in influencing online customer experiences and purchase intentions.

3) the sociability experience attributes

The respondents stated, "There are no interactions between audiences; I can't ask questions; the answers to my inquiries come in too late sometimes two weeks after the end of course; the chatbox is always off."

"Most of the time I have a particular goal in mind to attend this course, this makes me buy merchandise online at least twice in a month; I enjoy the online shopping the most; I attend from both channels, but when I have a specific goal in mind I go to the online channel as I can collect information conveniently, and compare between events quickly."

4) Usability

"I can access quickly and easily".

\subsubsection{Quantitative Method}

Phase two will use a quantitative method just like previous studies, in which data will be collected through surveys and then analyzed using statistical techniques, to test the hypotheses and interpret the results

Data will be collected using surveys, and will analyze data using statistical techniques. 


\subsection{Sampling Design and Plan}

\subsubsection{Research Population}

Table 4. Population of all Arab internet users who use the ARADO Facebook platform

\begin{tabular}{|c|c|c|c|c|c|c|c|c|}
\hline \multicolumn{3}{|l|}{ Age } & \multicolumn{3}{|l|}{ Gender } & \multicolumn{3}{|l|}{ Country } \\
\hline$(13-17)$ & 135 & $0.37 \%$ & Male & 28024 & $77.12 \%$ & Egypt & 15886 & $43.72 \%$ \\
\hline$(18-24)$ & 2888 & $7.95 \%$ & Female & 8312 & $22.88 \%$ & Algeria & 6489 & $17.86 \%$ \\
\hline$(25-34)$ & 14571 & $40.10 \%$ & & & & Libya & 3123 & $8.59 \%$ \\
\hline$(35-44)$ & 11669 & $32.11 \%$ & & & & Tunisia & 2339 & $6.44 \%$ \\
\hline$(45-54)$ & 4850 & $13.35 \%$ & & & & Iraq & 2214 & $6.09 \%$ \\
\hline$(55-64)$ & 1538 & $4.23 \%$ & & & & Morocco & 1249 & $3.44 \%$ \\
\hline \multirow[t]{39}{*}{$65+$} & 685 & $1.89 \%$ & & & & Yemen & 1212 & $3.34 \%$ \\
\hline & & & & & & Saudi Arabia & 678 & $1.87 \%$ \\
\hline & & & & & & Palestine & 452 & $1.24 \%$ \\
\hline & & & & & & Jordan & 346 & $0.95 \%$ \\
\hline & & & & & & Kuwait & 323 & $0.89 \%$ \\
\hline & & & & & & $\begin{array}{ll}\text { United } & \text { Arab } \\
\text { Emirates } & \\
\end{array}$ & 205 & $0.56 \%$ \\
\hline & & & & & & Syria & 186 & $0.51 \%$ \\
\hline & & & & & & Sudan & 183 & $0.50 \%$ \\
\hline & & & & & & Oman & 181 & $0.50 \%$ \\
\hline & & & & & & Qatar & 158 & $0.43 \%$ \\
\hline & & & & & & Bahrain & 135 & $0.37 \%$ \\
\hline & & & & & & India & 102 & $0.28 \%$ \\
\hline & & & & & & Pakistan & 92 & $0.25 \%$ \\
\hline & & & & & & Lebanon & 92 & $0.25 \%$ \\
\hline & & & & & & Turkey & 92 & $0.25 \%$ \\
\hline & & & & & & $\begin{array}{l}\text { United States of } \\
\text { America }\end{array}$ & 59 & $0.16 \%$ \\
\hline & & & & & & France & 59 & $0.16 \%$ \\
\hline & & & & & & Bangladesh & 56 & $0.15 \%$ \\
\hline & & & & & & South Sudan & 55 & $0.15 \%$ \\
\hline & & & & & & Philippines & 44 & $0.12 \%$ \\
\hline & & & & & & Germany & 38 & $0.10 \%$ \\
\hline & & & & & & Canada & 30 & $0.08 \%$ \\
\hline & & & & & & Malaysia & 29 & $0.08 \%$ \\
\hline & & & & & & United Kingdom & 26 & $0.07 \%$ \\
\hline & & & & & & Indonesia & 25 & $0.07 \%$ \\
\hline & & & & & & China & 22 & $0.06 \%$ \\
\hline & & & & & & Mauritania & 20 & $0.06 \%$ \\
\hline & & & & & & Somalia & 18 & $0.05 \%$ \\
\hline & & & & & & Italy & 17 & $0.05 \%$ \\
\hline & & & & & & Belgium & 16 & $0.04 \%$ \\
\hline & & & & & & Russia & 15 & $0.04 \%$ \\
\hline & & & & & & Nepal & 13 & $0.04 \%$ \\
\hline & & & & & & Sri Lanka & 12 & $0.03 \%$ \\
\hline & & & & & & Spain & 10 & $0.03 \%$ \\
\hline & & & & & & Kenya & 10 & $0.03 \%$ \\
\hline & & & & & & Thailand & 9 & $0.02 \%$ \\
\hline & & & & & & Ethiopia & 8 & $0.02 \%$ \\
\hline & & & & & & Vietnam & 8 & $0.02 \%$ \\
\hline & 36336 & $100 \%$ & & 36336 & $100 \%$ & & 36336 & $100 \%$ \\
\hline
\end{tabular}




\subsubsection{Research Sample}

- To collect data required to test the hypothesis, the research will draw a sample of 377 Arab internet users on Facebook platform from the size of the population. (Table 4)

- The research will use probability sampling techniques taking into consideration the internet users' time.

\subsubsection{Sampling Unit}

The sampling unit will be Arab online users who used the ARADO Facebook platform (Table 4).

\subsection{Measurement Scaling and Data Collection}

\subsubsection{The Proposed Model}

The research model in Figure (1) was based on a review of the literature. The proposed model consists of three primary constructs that exist within an online brand community setting, and are denoted as follows:

"Customer Experience" construct, "Customer Engagement" construct, and "Purchase Intention" construct. The objective of this study is to assess the relationships between these constructs and their interaction within the online brand community setting

The first construct is comprised of four customer experience variables measuring the (Pragmatic, Hedonic, Sociability and Usability) dimensions. The second construct is comprised of two customer engagement variables measuring the (Attitudinal and Behavioral) dimensions. The third construct measures the Purchase Intention dimension.

1) The First Construct - Online Customer Experience

To collect data on the first construct (dimension 1 and 2: Pragmatic and Hedonic), an seven-point multi-item semantic scale was adapted from Mathwick et al (2001) and Voss et al (2003). To assess dimension 3: Sociability, of the first construct, authors adapted a 5-point scale, based on an existing scale of measurement, in addition to using qualitative case studies (Gunawardena, 1995; Tu, 2002). As regards dimension 4: Usability, we will use methods employed by previous studies i.e. a six-point scale to measure this dimension (Brooke, 1996; Chin et al., 1988; Lewis, 1995; Tullis and Stetson, 2004).

2) The Second Construct - Customer Engagement Experience

This research study will measure customer engagement using a six-point scale (dimension 1: Attitudinal) and a four-point scale for (dimension 2: Behavioral) based on an approach that was adapted from Verleye et al (2014). The scale represents a behavioral manifestation of online users towards the ARADO virtual community that goes beyond the purchase from the view point of an Arab.

3) The Third Construct - Purchase Intention

The research study will measure customer purchase intention using a three-point scale based on Zeithaml et al., (1996) and extensive empirical studies that identified Arab internet user's intention to buy offers through connection to ARADO community.

\subsubsection{Data Collection}

Data will be collected using an online questionnaire that will be distributed among the randomly sampled units. 


\subsection{Research Variables and Measurements}

Table 5. Research variables and measurements

\begin{tabular}{|c|c|}
\hline Variables & $\begin{array}{l}\text { Measurement scales } \\
\text { 7- point semantic differential scale }\end{array}$ \\
\hline 1.”Online & 1. 1 "Worthy/worthless" \\
\hline Customer & 1. 2 "Useful/not useful" \\
\hline Experience & 1. 3 "Productive/not productive" \\
\hline \multirow[t]{5}{*}{ Pragmatic" } & 1. 4 "Valuable/not valuable" \\
\hline & 1. 5 "Practical/impractical" \\
\hline & 1. 6 "Informative/non informative" \\
\hline & 1. 7 "Relevant/irrelevant" \\
\hline & 1. 8 "Satisfying/unsatisfying" \\
\hline 2.’Online & 2. 1 "Happy/sad" \\
\hline Customer & 2. 2 "Pleasing/annoying" \\
\hline Experience & 2. 3 "Fun/not fun" \\
\hline \multirow[t]{7}{*}{ Hedonic" } & 2. 4 "Exciting/not exciting" \\
\hline & 2. 5 "Captivating/not captivating" \\
\hline & 2. 6 "Entertaining/not entertaining" \\
\hline & 2. 7 "Deeply engrossing/not deeply engrossing" \\
\hline & 2. 8 "Enjoyable/not enjoyable" \\
\hline & 2. 9 "Stimulating/boring" \\
\hline & 2. 10 "Absorbed intently/not absorbed intently" \\
\hline 3.’'Online & 3. 1 "Friendly/not friendly" \\
\hline Customer & 3. 2 "Communal/Lonesome" \\
\hline Experience & 3. 3 "Personal/impersonal" \\
\hline \multirow[t]{2}{*}{ Sociability" } & 3. 4 "Polite/impolite" \\
\hline & 3. 5 "Inviting/not inviting" \\
\hline 4.”Online & 4. 1 "Easy/difficult" \\
\hline Customer & 4. 2 "Not tiring/tiring" \\
\hline Experience & 4. 3 "Not stressful/stressful”' \\
\hline \multirow[t]{3}{*}{ Usability" } & 4. 4 "Not confusing/confusing" \\
\hline & 4. 5 "Simple/Complicated" \\
\hline & 4. 6 "Consistent/Not consistent" \\
\hline 5.'Customer & 5. 1 "I am heavily into this community", \\
\hline Attitudinal & 5. 2 "I am passionate about participating in this community" \\
\hline \multirow[t]{4}{*}{ Engagement" } & 5. 3 "I pay a lot of attention to anything about this community" \\
\hline & 5. 4 "Anything related to this community grabs my attention" \\
\hline & 5. 5 "I enjoy this community more when I am with others" \\
\hline & 5. 6 "This community is more fun when other people around me join it too" \\
\hline 6."Customer & 6. 1 "I adequately complete all expected behaviours in this community" \\
\hline Behavioral & 6. 2 "I do things to make the community's job easier" \\
\hline \multirow[t]{2}{*}{ Engagement" } & 6. 3 "I provide the community some useful suggestions to improve services" \\
\hline & 6. 4 "I help other members get what they need within this community" \\
\hline 7."Purchase & 7. 1 "I would purchase products or services through this community" \\
\hline \multirow[t]{2}{*}{ Intention" } & 7. 2 "The community is my first choice to buy relative products or services" \\
\hline & 7. 3 "I would do more businesses with this community in the next few years" \\
\hline
\end{tabular}

Source: prepared by the researcher

\subsection{Data Analysis}

1) Descriptive measures of central tendency.

2) Multiple Correlation and Regression analysis will be used to test Hypotheses 1-2-3.

3) Two sample/one sample T-Test will be used to describe the significance of the relationship between and dependent variables.

4) Pearson Correlation Coefficient will be used to measure the strength and direction of the relationship between the independent variables and the dependent variable. 
5) Path Analysis to test (Hypothesis 4) will be used to explore the effect of Customer Engagement on the relationship between Customer Experience and Purchase Intention.

\section{References}

Akaka, M. A., \& Vargo, S. L. (2015). Extending the context of service: from encounters to ecosystems. Journal of Services Marketing, 29(6-7), 453-462. https://doi.org/10.1108/JSM-03-2015-0126

Akaka, M. A., Vargo, S. L., \& Lusch, R. F. (2013). The complexity of context: A service ecosystems approach for international marketing. Journal of International Marketing, 21(4), 1-20. https://doi.org/10.1509/jim.13.0032

Algharabat, R., Rana, N. P., Dwivedi, Y. K., Alalwan, A. A., \& Qasem, Z. (2018). The effect of telepresence, social presence and involvement on consumer brand engagement: An empirical study of non-profit organizations. Journal of Retailing and Consumer Services, 40, 139-149. https://doi.org/10.1016/j.jretconser.2017.09.011

Arab Administrative Development Organization. (2020). About ARADO: ARADO background. Retrieved from http://www.arado.org/Content.aspx?s2=1048

Arab Administrative Development Organization. (2020). ARADO Facebook page: ARADO official. Retrieved from http://www.facebook.com/arado.official

Babin, B. J., Darden, W. R., \& Griffin, M. (1994). Work and/or fun: measuring hedonic and utilitarian shopping value. Journal of consumer research, 20(4), 644-656. https://doi.org/10.1086/209376

Baldus, B. J., Voorhees, C., \& Calantone, R. (2015). Online brand community engagement: Scale development and validation. Journal of business research, 68(5), 978-985. https://doi.org/10.1016/j.jbusres.2014.09.035

Batra, R., \& Ahtola, O. T. (1991). Measuring the hedonic and utilitarian sources of consumer attitudes. Marketing letters, 2(2), 159-170. https://doi.org/10.1007/BF00436035

Blumler, J. G. (1979). The role of theory in uses and gratifications studies. Communication research, 6(1), 9-36. https://doi.org/10.1177/009365027900600102

Bowden, J. L. H. (2009). The process of customer engagement: A conceptual framework. Journal of marketing theory and practice, 17(1), 63-74. https://doi.org/10.2753/MTP1069-6679170105

Bowden, J. L. H., Conduit, J., Hollebeek, L. D., Luoma-Aho, V., \& Solem, B. A. (2017). Engagement valence duality and spillover effects in online brand communities. Journal of Service Theory and Practice, 27(4), 877-897. https://doi.org/10.1108/JSTP-04-2016-0072

Brakus, J. J., Schmitt, B. H., \& Zarantonello, L. (2009). Brand experience: what is it? How is it measured? Does it affect loyalty?. Journal of marketing, 73(3), 52-68. https://doi.org/10.1509/jmkg.73.3.052

Bridges, E., \& Florsheim, R. (2008). Hedonic and utilitarian shopping goals: The online experience. Journal of Business research, 61(4), 309-314. https://doi.org/10.1016/j.jbusres.2007.06.017

Brodie, R. J., Hollebeek, L. D., Jurić, B., \& Ilić, A. (2011). Customer engagement: Conceptual domain, fundamental propositions, and implications for research. Journal of service research, 14(3), 252-271. https://doi.org/10.1177/1094670511411703

Brodie, R. J., Ilic, A., Juric, B., \& Hollebeek, L. (2013). Consumer engagement in a virtual brand community: An exploratory analysis. Journal of business research, 66(1), 105-114. https://doi.org/10.1016/j.jbusres.2011.07.029

Brooke, J. (1996). SUS-A quick and dirty usability scale. Usability evaluation in industry, 189(194), 4-7.

Carvalho, A., \& Fernandes, T. (2018). Understanding customer brand engagement with virtual social communities: A comprehensive model of drivers, outcomes and moderators. Journal of Marketing Theory and Practice, 26(1-2), 23-37. https://doi.org/10.1080/10696679.2017.1389241

Chahal, H., \& Rani, A. (2017). How trust moderates social media engagement and brand equity. Journal of Research in Interactive Marketing. https://doi.org/10.1108/JRIM-10-2016-0104

Chang, A., Hsieh, S. H., \& Tseng, T. H. (2013). Online brand community response to negative brand events: the role of group eWOM. Internet Research, 23(4), 486-506. https://doi.org/10.1108/IntR-06-2012-0107

Chen, S. C., \& Lin, C. P. (2015). The impact of customer experience and perceived value on sustainable social relationship in blogs: An empirical study. Technological Forecasting and Social Change, 96, 40-50. https://doi.org/10.1016/j.techfore.2014.11.011

Chin, J. P., Diehl, V. A., \& Norman, K. L. (1988, May). Development of an instrument measuring user satisfaction of the human-computer interface. In Proceedings of the SIGCHI conference on Human factors in computing systems, 
pp. 213-218. https://doi.org/10.1145/57167.57203

Chow, W. S., \& Shi, S. (2015). Investigating customers' satisfaction with brand pages in social networking sites. Journal of Computer Information Systems, 55(2), 48-58. https://doi.org/10.1080/08874417.2015.11645756

Creswell, J. W., \& Creswell, J. D. (2017). Research design: Qualitative, quantitative, and mixed methods approaches. Sage publications.

Csikszentmihalyi, M., \& NewYork, N. Y. (1990). Harper and Row. Flow: The psychology of optimal experience.

Culnan, M. J., McHugh, P. J., \& Zubillaga, J. I. (2010). How large US companies can use Twitter and other social media to gain business value. MIS Quarterly Executive, 9(4).

Delgado-Ballester, E., \& Sabiote, E. F. (2015). Brand experimental value versus brand functional value: which matters more for the brand?. European Journal of Marketing, 49(11/12), 1857-1879. https://doi.org/10.1108/EJM-02-2014-0129

Dessart, L., Veloutsou, C., \& Morgan-Thomas, A. (2015). Consumer engagement in online brand communities: a social media perspective. Journal of Product \& Brand Management, 24(1), 28-42. https://doi.org/10.1108/JPBM-06-2014-0635

Dhar, R., \& Wertenbroch, K. (2000). Consumer choice between hedonic and utilitarian goods. Journal of marketing research, 37(1), 60-71. https://doi.org/10.1509/jmkr.37.1.60.18718

Dong, X. S., Wang, C. Z., \& Zhao, X. (2010). Research on customer satisfaction, attitude loyalty, the behavior honest's dissymmetry antecedent. East China Economic Management, 24(1), 154-160.

Dutton, J. E., Dukerich, J. M., Harquail, C. V. (1994). Organizational images and member identification. Adm. Sci. $Q$. 39 (2), 239-263. https://doi.org/10.2307/2393235

Fishbein, M., \& Ajzen, I. (1977). Belief, attitude, intention, and behavior: An introduction to theory and research. Philosophy \& Rhetoric. 41(4), 842-844.

Forgas, J. P. (2000). Feeling is believing? The role of processing strategies in mediating affective influences. Emotions and beliefs: How feelings influence thoughts, 108. https://doi.org/10.1017/CBO9780511659904.005

Gentile, C., Spiller, N., \& Noci, G. (2007). How to sustain the customer experience: An overview of experience components that co-create value with the customer. European management journal, 25(5), 395-410. https://doi.org/10.1016/j.emj.2007.08.005

Grégoire, Y., Salle, A., \& Tripp, T. M. (2015). Managing social media crises with your customers: The good, the bad, and the ugly. Business Horizons, 58(2), 173-182. https://doi.org/10.1016/j.bushor.2014.11.001

Groeger, L., Moroko, L., \& Hollebeek, L. D. (2016). Capturing value from non-paying consumers' engagement behaviours: field evidence and development of a theoretical model. Journal of Strategic Marketing, 24(3-4), 190-209. https://doi.org/10.1080/0965254X.2015.1095223

Gummerus, J., Liljander, V., Weman, E., \& Pihlström, M. (2012). Customer engagement in a Facebook brand community. Management Research Review, 35(9), 857-877. https://doi.org/10.1108/01409171211256578

Gunawardena, C. N. (1995). Social presence theory and implications for interaction and collaborative learning in computer conferences. International journal of educational telecommunications, 1(2), 147-166.

Han, X., Kwortnik Jr, R. J., \& Wang, C. (2008). Service loyalty: An integrative model and examination across service contexts. Journal of Service Research, 11(1), 22-42. https://doi.org/10.1177/1094670508319094

Harmeling, C. M., Moffett, J. W., Arnold, M. J., \& Carlson, B. D. (2017). Toward a theory of customer engagement marketing. Journal of the Academy of marketing science, 45(3), 312-335. https://doi.org/10.1007/s11747-016-0509-2

Harrigan, P., Evers, U., Miles, M., \& Daly, T. (2017). Customer engagement with tourism social media brands. Tourism management, 59, 597-609. https://doi.org/10.1016/j.tourman.2016.09.015

Hirschman, E. C., \& Holbrook, M. B. (1982). Hedonic consumption: emerging concepts, methods and propositions. Journal of marketing, 46(3), 92-101. https://doi.org/10.1177/002224298204600314

Hoffman, D. L., \& Fodor, M. (2010). Can you measure the ROI of your social media marketing?. MIT Sloan Management Review, 52(1), 41.

Hoffman, D. L., \& Novak, T. P. (1996). Marketing in hypermedia computer-mediated environments: Conceptual foundations. Journal of marketing, 60(3), 50-68. https://doi.org/10.2307/1251841 
Hollebeek, L. D. (2011a). Exploring customer brand engagement: definition and themes. Journal of strategic Marketing, 19(7), 555-573. https://doi.org/10.1080/0965254X.2011.599493

Hollebeek, L. D. (2011b). Demystifying customer brand engagement: Exploring the loyalty nexus. Journal of marketing management, 27(7-8), 785-807. https://doi.org/10.1080/0267257X.2010.500132

Hollebeek, L. D., \& Chen, T. (2014). Exploring positively-versus negatively-valenced brand engagement: a conceptual model. Journal of Product \& Brand Management, 23(1), 62-74. https://doi.org/10.1108/JPBM-06-2013-0332

Hollebeek, L. D., Conduit, J., \& Brodie, R. J. (2016). Strategic drivers, anticipated and unanticipated outcomes of customer engagement. https://doi.org/10.1080/0267257X.2016.1144360

Hollebeek, L. D., Glynn, M. S., \& Brodie, R. J. (2014). Consumer brand engagement in social media: Conceptualization, scale development and validation. Journal of interactive marketing, 28(2), 149-165. https://doi.org/10.1016/j.intmar.2013.12.002

Honeycutt, C. (2005). Hazing as a process of boundary maintenance in an online community. Journal of computer-mediated communication, 10(2), JCMC1021. https://doi.org/10.1111/j.1083-6101.2005.tb00240.x

Hoyer, W. D., Chandy, R., Dorotic, M., Krafft, M., \& Singh, S. S. (2010). Consumer cocreation in new product development. Journal of service research, 13(3), 283-296. https://doi.org/10.1177/1094670510375604

Islam, J. U., \& Rahman, Z. (2016). Linking customer engagement to trust and word-of-mouth on Facebook brand communities: An empirical study. Journal of Internet Commerce, 15(1), 40-58. https://doi.org/10.1080/15332861.2015.1124008

Jaakkola, E., \& Alexander, M. (2014). The role of customer engagement behavior in value co-creation: a service system perspective. Journal of service research, 17(3), 247-261. https://doi.org/10.1177/1094670514529187

Jones, M. A., Reynolds, K. E., \& Arnold, M. J. (2006). Hedonic and utilitarian shopping value: Investigating differential

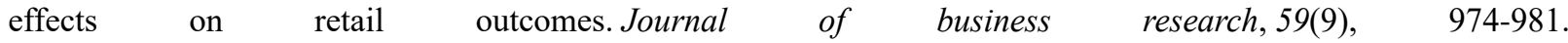
https://doi.org/10.1016/j.jbusres.2006.03.006

Kaplan, A. M., \& Haenlein, M. (2010). Users of the world, unite! The challenges and opportunities of Social Media. Business horizons, 53(1), 59-68. https://doi.org/10.1016/j.bushor.2009.09.003

Kim, A. J., \& Ko, E. (2012). Do social media marketing activities enhance customer equity? An empirical study of luxury fashion brand. Journal of Business research, 65(10), 1480-1486. https://doi.org/10.1016/j.jbusres.2011.10.014

Kortam, W. (2006). Exploring Foundations for the Diffusion of Internet Marketing Research and Practice: A Conceptual Framework and Empirical Analysis. Scientific Journal of Management.

Koskela-Huotari, K., Edvardsson, B., Jonas, J. M., Sörhammar, D., \& Witell, L. (2016). Innovation in service ecosystems-Breaking, making, and maintaining institutionalized rules of resource integration. Journal of Business Research, 69(8), 2964-2971. https://doi.org/10.1016/j.jbusres.2016.02.029

Kotler, P., \& Gertner, D. (2011). A place marketing and place branding perspective revisited. Destination brands: Managing place reputation, 3, 33-53. https://doi.org/10.1016/B978-0-08-096930-5.10003-5

Kusumasondjaja, S. (2012). Travelers' responses to online information on consumer-generated media for travel-related services (Doctoral dissertation, Curtin University).

Leventhal, R. C., Hollebeek, L. D., \& Chen, T. (2014). Exploring positively-versus negatively-valenced brand engagement: a conceptual model. Journal of Product \& Brand Management. https://doi.org/10.1108/JPBM-06-2013-0332

Lewis, J. R. (1995). IBM computer usability satisfaction questionnaires: psychometric evaluation and instructions for use. International Journal of Human-Computer Interaction, 7(1), https://doi.org/10.1080/10447319509526110

Lewis, R. C., \& Chambers, R. E. (2000). Marketing Leadership in Hospitality: Foundations and Practices, 3rd ed., John Wiley \& Sons, Inc., New York, NY.

Li, H., Li, P., \& Zhang, J. (2009). A Study on Determinants of Customer-Company Identification: Evidence from the Retailing Banking Industry. Science of Science and Management of S. \& T., 30 (12), 169-177.

López, M., \& Sicilia, M. (2014). Determinants of E-WOM influence: the role of consumers' internet experience. Journal of theoretical and applied electronic commerce research,9(1), 28-43. https://doi.org/10.4067/S0718-18762014000100004 
Lusch, R. F., \& Nambisan, S. (2015). Service innovation: A service-dominant logic perspective. MIS quarterly, 39(1), 155-176. https://doi.org/10.25300/MISQ/2015/39.1.07

Lusch, R. F., \& Vargo, S. L. (2010). SD logic: accommodating, integrating, transdisciplinary. Grand Service Challenge, University of Cambridge, September, 23.

Malhotra, N. K., Birks, D. K., \& Wills, P. (2010). Marketing Research: An Applied Orientation (6th Europian ed.). England: Pearson Education Limited.

Mathwick, C., Malhotra, N., \& Rigdon, E. (2001). Experiential value: conceptualization, measurement and application in the catalog and Internet shopping environmentis. Journal of retailing, 77(1), 39-56. https://doi.org/10.1016/S0022-4359(00)00045-2

Mollen, A., \& Wilson, H. (2010). Engagement, telepresence and interactivity in online consumer experience: Reconciling scholastic and managerial perspectives. Journal of business research,63(9-10), 919-925. https://doi.org/10.1016/j.jbusres.2009.05.014

Mummalaneni, V. (2005). An empirical investigation of web site characteristics, consumer emotional states and online shopping behaviors. Journal of Business Research, 58(4), https://doi.org/10.1016/S0148-2963(03)00143-7

Muniz, A. M. (2001). O'Guinn, TC (2001): Brand Community. Journal of consumer research, 27(4), 412-432. https://doi.org/10.1086/319618

Nambisan, P., \& Watt, J. H. (2011). Managing customer experiences in online product communities. Journal of Business Research, 64(8), 889-895. https://doi.org/10.1016/j.jbusres.2010.09.006

Nambisan, S., \& Nambisan, P. (2008). How to profit from a better'virtual customer environment'. MIT Sloan management review, 49(3), 53.

Newberry, C. (2019). 1301 Social media statistics that matter to marketers in 2019. Available at:https://blog.hootsuite.com/social-media-statistics-for-social-media managers/\#general (accessed 3 June 2020).

Nielsen, J. (2000). Designing web usability.

Noble, S. M., Griffith, D. A., \& Weinberger, M. G. (2005). Consumer derived utilitarian value and channel utilization in a multi-channel retail context. Journal of Business Research, 58(12), 1643-1651. https://doi.org/10.1016/j.jbusres.2004.10.005

Okazaki, S., Rubio, N., \& Campo, S. (2014). Gossip in social networking sites: Why people chitchat about ad campaigns. International Journal of Market Research, 56(3), 317-340. https://doi.org/10.2501/IJMR-2014-022

Overby, J. W., \& Lee, E. J. (2006). The effects of utilitarian and hedonic online shopping value on consumer preference and intentions. Journal of Business research, 59(10-11), 1160-1166. https://doi.org/10.1016/j.jbusres.2006.03.008

Pansari, A., \& Kumar, V. (2017). Customer engagement: the construct, antecedents, and consequences. Journal of the Academy of Marketing Science, 45(3), 294-311. https://doi.org/10.1007/s11747-016-0485-6

Park, H., \& Kim, Y. K. (2014). The role of social network websites in the consumer-brand relationship. Journal of Retailing and Consumer Services, 21(4), 460-467. https://doi.org/10.1016/j.jretconser.2014.03.011

Patterson, P., Yu, T., \& De Ruyter, K. (2006, December). Understanding customer engagement in services. In Advancing theory, maintaining relevance, proceedings of ANZMAC 2006 conference, Brisbane, pp. 4-6.

Pentina, I., Amialchuk, A., \& Taylor, D. G. (2011). Exploring effects of online shopping experiences on browser satisfaction and e-tail performance. International Journal of Retail \& Distribution Management. https://doi.org/10.1108/09590551111162248

Porter, C. E., Donthu, N., MacElroy, W. H., \& Wydra, D. (2011). How to foster and sustain engagement in virtual communities. California management review, 53(4), 80-110. https://doi.org/10.1525/cmr.2011.53.4.80

Prahalad, C. K., \& Ramaswamy, V. (2004). Co-creation experiences: The next practice in value creation. Journal of interactive marketing, 18(3), 5-14. https://doi.org/10.1002/dir.20015

Preece, J., \& Preece, J. (2000). Online communities: Designing usability, supporting sociability.

Prentice, C., \& Loureiro, S. M. C. (2018). Consumer-based approach to customer engagement-The case of luxury brands. Journal of Retailing and Consumer Services, 43, 325-332. https://doi.org/10.1016/j.jretconser.2018.05.003

Rheingold, H. (1993). The virtual community: Homesteading on the electronic frontier. MIT press.

Ridings, C. M., Gefen, D., \& Arinze, B. (2002). Some antecedents and effects of trust in virtual communities. The 
journal of strategic Information Systems, 11(3-4), 271-295. https://doi.org/10.1016/S0963-8687(02)00021-5

Rose, S., Clark, M., Samouel, P., \& Hair, N. (2012). Online customer experience in e-retailing: an empirical model of antecedents and outcomes. Journal of retailing, 88(2), 308-322. https://doi.org/10.1016/j.jretai.2012.03.001

Rose, S., Hair, N., \& Clark, M. (2011). Online customer experience: A review of the business-to-consumer online purchase context. International Journal of Management Reviews, 13(1), 24-39. https://doi.org/10.1111/j.1468-2370.2010.00280.x

Royo-Vela, M., \& Casamassima, P. (2011). The influence of belonging to virtual brand communities on consumers' affective commitment, satisfaction and word-of-mouth advertising. Online Information Review. https://doi.org/10.1108/14684521111161918

Schamari, J., \& Schaefers, T. (2015). Leaving the home turf: How brands can use webcare on consumer-generated platforms to increase positive consumer engagement. Journal of Interactive Marketing, 30, 20-33. https://doi.org/10.1016/j.intmar.2014.12.001

Schmitt, B. (1999). Experiential marketing. Journal of marketing management, 15(1-3), 53-67. https://doi.org/10.1362/026725799784870496

Seo, E. J., \& Park, J. W. (2018). A study on the effects of social media marketing activities on brand equity and customer response in the airline industry. Journal of Air Transport Management, 66, 36-41. https://doi.org/10.1016/j.jairtraman.2017.09.014

Shen, B., \& Bissell, K. (2013). Social media, social me: A content analysis of beauty companies' use of Facebook in marketing and branding. Journal of Promotion Management, 19(5), 629-651. https://doi.org/10.1080/10496491.2013.829160

Shneiderman, B., \& Plaisant, C. (2004). Designing the user interface: strategies for effective human-computer interaction. Pearson.

Simon, C., Brexendorf, T. O., \& Fassnacht, M. (2016). The impact of external social and internal personal forces on consumers' brand community engagement on Facebook. Journal of Product \& Brand Management. https://doi.org/10.1108/JPBM-03-2015-0843

Skålén, P., Gummerus, J., Von Koskull, C., \& Magnusson, P. R. (2015). Exploring value propositions and service innovation: a service-dominant logic study. Journal of the Academy of Marketing Science,43(2), 137-158. https://doi.org/10.1007/s11747-013-0365-2

So, K. K. F., King, C., \& Sparks, B. (2014). Customer engagement with tourism brands: Scale development and validation. Journal of Hospitality \& Tourism Research, 38(3), 304-329. https://doi.org/10.1177/1096348012451456

Stelzner, M. (2018). Social media marketing industry report: how marketers are using social media to grow their businesses. Available at:

https://mybizonlineservices.com/2018/08/SocialMediaMarketing_Industry-Report-2018_Social_Examiner.pdf (accessed 3 June 2020).

Thompson, S. A., \& Sinha, R. K. (2008). Brand communities and new product adoption: The influence and limits of oppositional loyalty. Journal of marketing, 72(6), 65-80. https://doi.org/10.1509/jmkg.72.6.065

$\mathrm{Tu}, \mathrm{C} . \mathrm{H}$. (2002). The measurement of social presence in an online learning environment. International Journal on E-learning, 1(2), 34-45. https://doi.org/10.1080/09523980010021235

Tullis, T. S., \& Stetson, J. N. (2004, June). A comparison of questionnaires for assessing website usability. In Usability professional association conference, 1 .

Van Doorn, J., Lemon, K. N., Mittal, V., Nass, S., Pick, D., Pirner, P., \& Verhoef, P. C. (2010). Customer engagement behavior: Theoretical foundations and research directions. Journal of service research, 13(3), 253-266. https://doi.org/10.1177/1094670510375599

Vargo, S. L., \& Akaka, M. A. (2012). Value cocreation and service systems (re) formation: A service ecosystems view. Service Science, 4(3), 207-217. https://doi.org/10.1287/serv.1120.0019

Vargo, S. L., \& Lusch, R. F. (2008). Service-dominant logic: continuing the evolution. Journal of the Academy of marketing Science, 36(1), 1-10. https://doi.org/10.1007/s11747-007-0069-6

Vargo, S. L., \& Lusch, R. F. (2011). It's all B2B... and beyond: Toward a systems perspective of the market. Industrial marketing management, 40(2), 181-187. https://doi.org/10.1016/j.indmarman.2010.06.026

Vargo, S. L., \& Lusch, R. F. (2014). Evolving to a new dominant logic for marketing. In The Service-Dominant Logic of 
Marketing, pp. 21-46. Routledge.

Vargo, S. L., \& Lusch, R. F. (2016). Institutions and axioms: an extension and update of service-dominant logic. Journal of the Academy of marketing Science, 44(1), 5-23. https://doi.org/10.1007/s11747-015-0456-3

Venkatesh, V., \& Agarwal, R. (2006). Turning visitors into customers: A usability-centric perspective on purchase behavior in electronic channels. Management Science, 52(3), 367-382. https://doi.org/10.1287/mnsc.1050.0442

Verhoef, P. C., Reinartz, W. J., \& Krafft, M. (2010). Customer engagement as a new perspective in customer management. Journal of service research, 13(3), 247-252. https://doi.org/10.1177/1094670510375461

Verleye, K., Gemmel, P., \& Rangarajan, D. (2014). Managing engagement behaviors in a network of customers and stakeholders: Evidence from the nursing home sector. Journal of service research, 17(1), 68-84. https://doi.org/10.1177/1094670513494015

Vivek, S. D., Beatty, S. E., \& Morgan, R. M. (2012). Customer engagement: Exploring customer relationships beyond purchase. Journal of marketing theory and practice, 20(2), 122-146. https://doi.org/10.2753/MTP1069-6679200201

Vivek, S. D., Beatty, S. E., Dalela, V., \& Morgan, R. M. (2014). A generalized multidimensional scale for measuring customer engagement. Journal of Marketing Theory and Practice, 22(4), 401-420. https://doi.org/10.2753/MTP1069-6679220404

Voss, C. A., Roth, A. V., Rosenzweig, E. D., Blackmon, K., \& Chase, R. B. (2004). A tale of two countries' conservatism, service quality, and feedback on customer satisfaction. Journal of Service Research,6(3), 212-230. https://doi.org/10.1177/1094670503260120

Voss, K. E., Spangenberg, E. R., \& Grohmann, B. (2003). Measuring the hedonic and utilitarian dimensions of consumer attitude. Journal of marketing research, 40(3), 310-320. https://doi.org/10.1509/jmkr.40.3.310.19238

Wang, Y., \& Fesenmaier, D. R. (2004). Modeling participation in an online travel community. Journal of Travel Research, 42(3), 261-270. https://doi.org/10.1177/0047287503258824

Wirtz, J., Den Ambtman, A., Bloemer, J., Horváth, C., Ramaseshan, B., Van De Klundert, J., ... Kandampully, J. (2013). Managing brands and customer engagement in online brand communities. Journal of Service Management, 24(3), 223-244. https://doi.org/10.1108/09564231311326978

Xu, C., Ryan, S., Prybutok, V., \& Wen, C. (2012). It is not for fun: An examination of social network site usage. Information \& Management, 49(5), 210-217. https://doi.org/10.1016/j.im.2012.05.001

Yu, X., Yuan, C., Kim, J., \& Wang, S. (2020). A new form of brand experience in online social networks: An empirical analysis. Journal of Business Research. https://doi.org/10.1016/j.jbusres.2020.02.011

Zeithaml, V. A., Berry, L. L., \& Parasuraman, A. (1996). The behavioral consequences of service quality. Journal of marketing, 60(2), 31-46. https://doi.org/10.2307/1251929

Zhang, H., Lu, Y., Gupta, S., \& Zhao, L. (2014). What motivates customers to participate in social commerce? The impact of technological environments and virtual customer experiences. Information \& Management, 51(8), 1017-1030. https://doi.org/10.1016/j.im.2014.07.005

Zhang, H., Lu, Y., Wang, B., \& Wu, S. (2015). The impacts of technological environments and co-creation experiences on customer participation. Information \& Management, 52(4), 468-482. https://doi.org/10.1016/j.im.2015.01.008

Zhang, M., \& Luo, N. (2016). Understanding relationship benefits from harmonious brand community on social media. Internet Research. https://doi.org/10.1108/IntR-05-2015-0149

Zhang, T., Lu, C., \& Kizildag, M. (2017). Engaging generation Y to co-create through mobile technology. International Journal of Electronic Commerce, 21(4), 489-516. https://doi.org/10.1080/10864415.2016.1355639

\section{Notes}

Note 1. the statistical tests are associated with the selected analytical techniques in the statistical package SPSS v.22 and AMOS.21.

\section{Copyrights}

Copyright for this article is retained by the author(s), with first publication rights granted to the journal.

This is an open-access article distributed under the terms and conditions of the Creative Commons Attribution license which permits unrestricted use, distribution, and reproduction in any medium, provided the original work is properly cited. 